ON THE OLD-JAVANESE CANTAKAPARWA

AND

ITS TALE OF SUTASOMA 




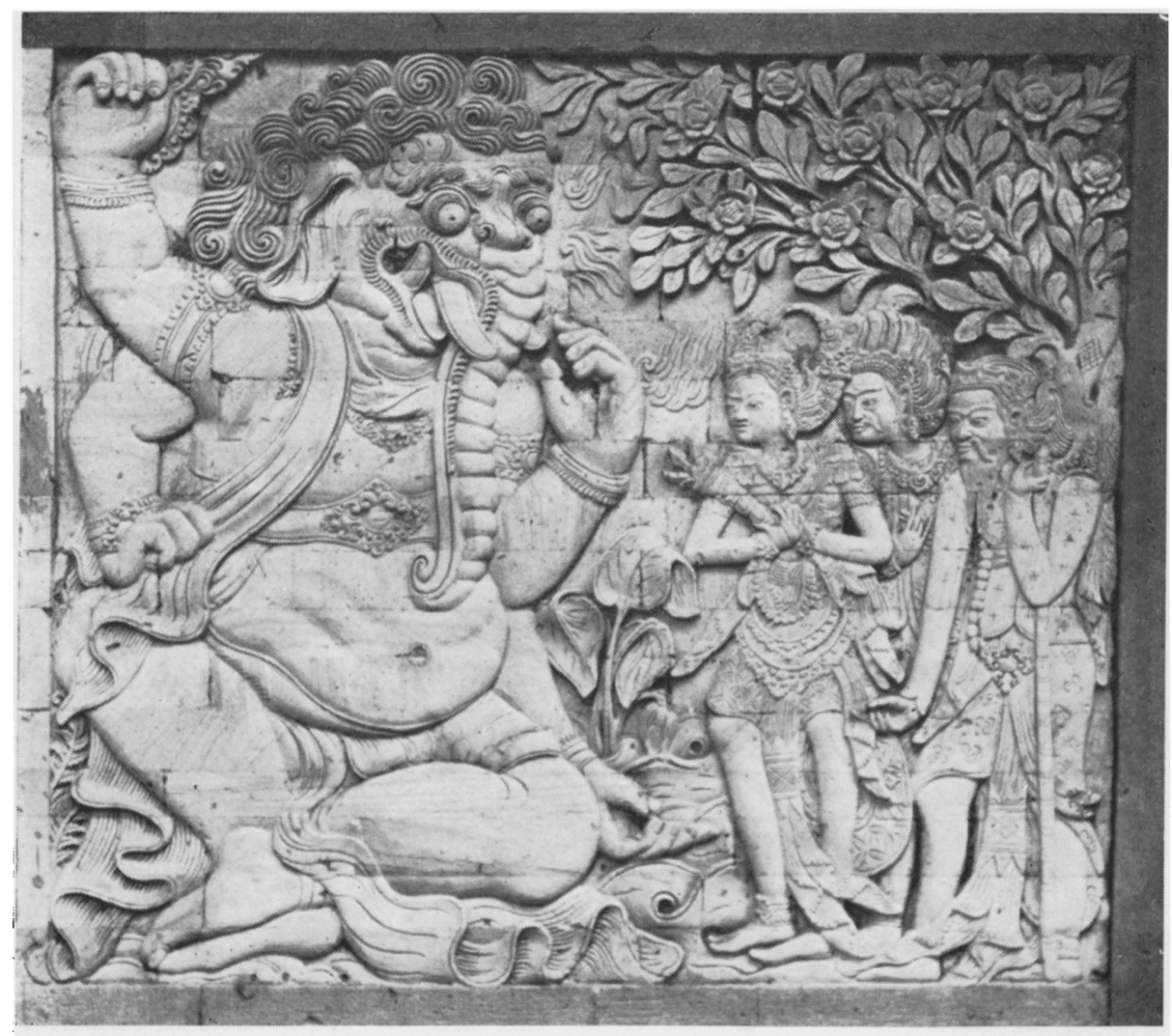

SUTASOMA PACIFYING GAJAWAKTRA

(Sec note on pauc IX) 


\title{
VERHANDELINGEI
}

VAN HET KONINKLIJK INSTITUUT VOOR

TAAL-, LAND. EN VOLKENKUNDE

\author{
DEEL 54
}

J. ENSINK

\section{ON THE OLD-JAVANESE CANTAKAPARWA AND ITS TALE OF SUTASOMA}

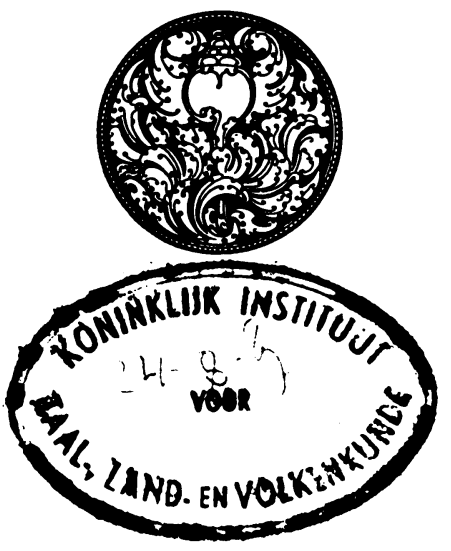

'S.GRAVEN HAGE-MARTINUS N IJ HOFF-1967 



\section{CON T E N T S}

Preface . . . . . . . . . . . . . . . . . . VII

Note to the frontispiece . . . . . . . . . . . . . IX

Abbreviations . . . . . . . . . . . . . . . . XI

I. INTRODUCTION . . . . . . . . . . . . . . 1

1. Character in general . . . . . . . . . . 1

2. Parwa . . . . . . . . . . . . . . . 1

3. Lexicography and linguistics . . . . . . . . 3

4. Manuscripts . . . . . . . . . . . . . 4

5. Identity and name. . . . . . . . . . . . . 6

6. Author . . . . . . . . . . . . . . . 8

7. Contents. Bhānwātmajaparwa . . . . . . . . 9

8. Caṇakiraṇa . . . . . . . . . . . . . . . 10

9. Wiwudaparwa; Pralapitaparwa . . . . . . . 10

10. Sutasoma . . . . . . . . . . . . . . 10

11. Cayabirama; Suprasena . . . . . . . . . . 12

12. Kapiparwa . . . . . . . . . . . . . . 12

13. Language . . . . . . . . . . . . . . 13

14. Time of composition . . . . . . . . . . . 13

15. Place . . . . . . . . . . . . . . . . 14

16. Use. Wayañ . . . . . . . . . . . . . . 14

17. Value for the history of literature . . . . . . 17

II. THE TALE OF SUTASOMA . . . . . . . . . . 20

Text with various readings . . . . . . . . . . . . 20

Translation . . . . . . . . . . . . . . . . . 21

Notes to the translation . . . . . . . . . . . . . 59

Index of names . . . . . . . . . . . . . . . . 63 



\section{P R E F A C E}

This study of the Old-Javanese Cantakaparwa at first was undertaken in order to draw from it material for the study of mpu Tantular's Sutasoma kakawin, an edition and translation of which I hope to publish in the course of time. On making acquaintance with the Cantakaparwa however, it seemed useful to me, not only to make the tale of Sutasoma accessible, but also to publish a few notes on the text in general. Though it obviously has been appreciated by Balinese students of ancient literature, the Cantakaparwa so far has become little known among scholars outside Bali. Maybe the interest has suffered from the low esteem in which the text was held by Van der Tuuk. My reading in it has led me to disagree with the great scholar on this point. From the tale of Sutasoma I trust to have made plausible that the Cantakaparwa may shed light on the history of epic themes in Old-Javanese literature. I may add that, to my mind, careful study of other tales, e.g. that of Suprasena, might yield similar results.

The purpose of my study in the Cantakaparwa did not go farther than this. I did not intend to give a complete survey of the contents of the text and the problems connected with it, useful though such work would be.

The manuscript for this paper was completed five years ago. It is pointless to go into the reasons why only now it is offered to the Board of Editors of the Royal Institute of Linguistics and Anthropology. Suffice it to say that many parts of the introduction have been recast.

The delay in the publication and the necessity of rewriting large portions had a consequence that was very welcome to me. Thanks to a grant from the Netherlands Organisation for the Advancement of Pure Research, in $1964 \mathrm{I}$ had the opportunity to work in Java and Bali for more than three months and in India for another quarter of a year. During that time I collected much information that also has its bearing on the Cantakaparwa. The recast has enabled me both to incorporate most of that information and to mention with profound gratitude the names of my informants, I Wajan Dalang of Padangtegal, I Gusti 
Ktut Gde of Denpasar, I Wajan Mendra of Bratan (Singaradja), and I Gusti Ngurah Ktut Sangka of Krambitan.

Dr. C. Hooykaas and Dr. Th. Pigeaud right from the beginning of my work on the Cantakaparwa have put me under no small obligation, the one by the loan of typewritten copies of Kirtya MSS, the other by various information and help in finding the required MSS, but still it is hard to say what has been more important for me: their material help or their constant encouragement.

Prof. Dr. A. Teeuw in a few places suggested a better translation, which I have accepted with thanks. If the interest he has taken in the publication is to be understood as resulting from the task of an editor, it testifies to a high notion of that task.

Mrs. G. van Baaren-Pape has corrected my English. I am much indebted to her for the care she devoted to the manuscript and her understanding and patience in helping me to the correct expression. 


\section{NOTE TO THE FRONTISPIECE}

The frontispiece shows one of a series of reliefs by I Gusti Njoman Lempad on a building in Puri Lingsir, Ubud, Bali.

The painter-sculptor I Gusti Njoman Lempad is one of the most remarkable artists of Bali today. He was born in Bedulu 1873. His father sent him to Ubud, where he still lives. On his work see Th. P. Galestin, Hedendaagse Kunst van Bali (Catalogue Exhibition Centraal Museum Utrecht 1962) p. 60 sqq. On his work in the Museum Puri Lukisan Ubud the catalogue (Indonesian and English) of that Museum published 1964.

In his sculptural work he was as a rule assisted by his daughter $\mathrm{Ni}$ Gusti Aju Oka. The series of reliefs of which the frontispiece is one, illustrates the beginning of the tale of Sutasoma. The other panels show (1) the fight of Gajawaktra and the nāga, (2) the tigress attacking Sutasoma, (3) Sutasoma giving instruction to Gajawaktra, the nāga and the tigress, (4) Indra's attempt to seduce Sutasoma, (5) Sutasoma before his parents, and (6) Sutasoma received by Sumitra. Relief 6 is dated 4-10-52. As the artist has not received a literary education, he does not know the tales from the kakawins, but from oral tradition and wayan (in his sculpture the hero is accompanied by panasars; cf. $\S 16)$. He has also made a series of drawings in ink showing scenes from Sutasoma's life until his meeting with Daśabāhu (Cf. Ensink, Sut. Onderzoek 105). Both drawings and sculptures testify to the artist's originality and speculative reflection on the subjects he depicts. In his works Sutasoma is usually accompanied by a Śaiwite priest (padanda sizwa) and a Buddhist priest (padanda Buddha). Accordingly in the relief shown here the figures behind the prince are those two priests (the one with the beard being the padanda Buddha), not Kesiawa and another recluse as we would presume from the texts. The sculpture illustrates what is told Sut. CP 81b.

Lempad's too are the panels with scenes from the story of Abhimanyu and Siti Sundari in the outer court of Puri Saren, Ubud. See the notes by Tjokorda Gede Agung Sukawati and G. J. Resink in Hans Rhodius, Schönheit und Reichtum des Lebens Walter Spies (Den Haag, n.d.), p. 409 sqq. 



\section{A B B R E V I A T I O N S}

Ādip.OJ Adiparwa. Oudjavaansch prozageschrift, uitgegeven door H. H. Juynboll, 's-Gravenhage 1906.

BKI

Bijdragen tot de Taal-, Land- en Volkenkunde (van Nederlandsch-Indië).

Brandes, J. Brandes. Beschrijving der Javaansche, Balineesche Beschr. en Sasaksche handschriften, aangetroffen in de nalatenschap van Dr. H. N. van der Tuuk en door hem vermaakt aan de Leidsche Universiteitsbibliotheek. 4 vols. Batavia 1901-1926.

CK Caṇụakiraṇa. See $\S 3$.

CP Cantakaparwa. References are to pages of MS D.

D Cod. Or. Leiden 4572. See $§ 4$.

Ensink, J. Ensink. Het Oudjavaanse gedicht Sutasoma. OnSut. Onderzoek derzoek op Java en Bali. Z.W.O. Jaarboek 1964. 's-Gravenhage 1965, p. 103 sqq.

G Cod. Or. Leiden Bruikleen Berg nr. 71. See $\S 4$.

Gonda, Skt. J. Gonda. Sanskrit in Indonesia. in Indonesia Nagpur, 1952.

$\mathrm{H} \quad$ Cod. Or. Leiden 6435. See $\S 4$.

Hazeu, G. A. J. Hazeu. Bijdrage tot de kennis van het Jav. tooneel Javaansche tooneel. Thesis Leiden 1897.

HNF Handelingen Nederlands Filologencongres.

Hooykaas, AT C. Hooykaas. Agama Tīrtha, Five studies in HinduBalinese religion. Verhandelingen KNAWL. Nieuwe Reeks, deel LXX No. 4. 
Juynboll, $\quad$ H. H. Juynboll. Supplement op den catologus van Suppl. Catal. de Javaansche en Madoereesche handschriften der Leidsche Universiteitsbibliotheek. 2 vols. Leiden, 1907-1911.

K $\quad$ MS Kirtya 389. See $§ 4$.

KBW H. N. van der Tuuk. Kawi-Balineesch-Nederlandsch woordenboek. 4 vols. Batavia, 1897-1912.

KNAWL Koninklijke (Nederlandse) Akademie van Wetenschappen, Afd. Letterkunde.

Krwś. Korawāśrama. References are to page and line of Korawāçrama. Een Oud-Javaansch prozageschrift, uitgegeven, vertaald en toegelicht door J. L. Swellengrebel. Thesis Leiden 1936.

L $\quad$ Cod. Or. Leiden 4577. See $\S 4$.

MBh. Mahābhārata. References are to book, adhyāya and sloka of the edition by V. S. Sukthankar a.o. Poona, 1933-.

Mc Phee, Colin Mc Phee, The Balinese wajang koelit and its Wajang koelit music. Djawa 16 (1936), pp. 1-34.

$\mathrm{R}$ Cod. Or. Leiden 9845. See $\S 4$.

Sut. CP The tale of Sutasoma (CP 78a-87b). See pp. 20-57.

Sut. k. Mpu Tantular. Puruṣāda śānta, also entitled Sutasoma kakawin.

Sut. 1. I Wj. Mendra. Lampahan Sutasoma. See p. 2, note 6 .

TBG Tijdschrift voor Indische taal-, land- en volkenkunde, uitgegeven door het (Koninklijk) Bataviaasch Genootschap van Kunsten en Wetenschappen.

Van der Tuuk, H. N. van der Tuuk. Notes on the Kawi Language Notes and Literature. Journal of the Royal Asiatic Society, New Series, vol. XIII (1881) p. 42 sqq.

VBG Verhandelingen (Koninklijk) Bataviaasch Genootschap van Kunsten en Wetenschappen.

VG H. Kern. Verspreide Geschriften. 17 vols. 's-Gravenhage, 1913-1936. 


\section{N T R O D U C T I O N}

\section{Character in general.}

The Old-Javanese Cantakaparwa has an encyclopaedic character. Prose narrations of myths and epic stories form the greater part of the book, but they are preceded, and their succession is sometimes interrupted by, paragraphs on the Old-Javanese language, esp. lexicography. The aim with which the work was composed may have been to impart all kinds of knowledge essential for the study of Old-Javanese literature. In the composition some parts have been borrowed literally from older texts, but more often they evidently are, or seem to be, recasts of works from Old-Javanese literature.

\section{Parwa.}

The title describes it as belonging to the parwa genre.

Sanskrit parvan-is a well-known term for the eighteen books of the Mahābhārata. Short prose versions of these books are among the oldest products of Old-Javanese literature that have come down to us and they appear to have inspired many later works. From their time onwards there are in the meaning of Old-Javanese parwa two elements, of which now one, then the other was more important: (1) the prose form and (2) the epic contents.

As to the form, some texts seem to derive their designation as a parwa only from their prose form. The Agastyaparwa ${ }^{1}$ is a prose text containing teachings of a purānic character.

Yet as a rule parwa denotes epic matter that somehow is related to the Mahābhärata-cycle: in Bali up to the present day wayain parwa is that shadow theatre in which stories from the Mahābhārata, or stories that may be connected with it, are staged. ${ }^{2}$ If the Buddhist tale

1 Agastyaparwa, een Oud-Javaansch proza-geschrift, uitgegeven en vertaald door J. Gonda. The Hague, $1936=$ BKI XC 329-419, XCII 337-468, XCIV $223-285$.

2 Here and in $\S 16$ I recapitulate parts of a paper on "Wajang en wajangliteratuur op Bali", read to the Dutch Congress of Philologists in 1966 and summarized in HNF XXIX 196 sq. See also Mc Phee, Wajang koelit. 
of Sutasoma is included in the repertoire of this wayan, this seems to be justified by the hero's belonging to the Kaurava dynasty, ${ }^{3}$ but wayan Rāmāyana is distinguished from wayan parwa. ${ }^{4}$ The wayan puppeteer (dalan) in South Bali at the beginning of a play often reads a formula called pañacah parwa (specification of the parwa). 5 The North-Balinese dalan I Wajan Mendra in the beginning of his performance of Sutasoma 6 used to pronounce the panaksaman pawayanan (prayer for forgiveness in wayan) 7 instead, which also gives the names of the parwas. Both pañacah parwa and panaksaman parayainan must be understood as a reference to the authority of the (Mahābhārata-)parwas.

But in fact the performance is seldom directly based on the parwas. 8 If a poetic (kakawin) version is available, the dalan preferably follows it, frequently quoting one or more stanzas. This illustrates that, though parwas as texts are in prose, parwa $m$ atter may be retold in poetic form in kakawins and dramatized in wayan.

The Old-Javanese kakawin is a poetical work modelled on the type of kãvya that in Sanskrit poetic doctrine is defined as sargabandha. As such Hooykaas has explained it in detail, taking the Rāmāyana kakawin as an example. 9 We recapitulate its chief features. The kakawin consists of a number of cantos in Indian metres; it takes its subject preferably from the epics (Sanskrit itihäsa); it evokes the poetic sentiments (Sanskrit rasa); it uses language embellished both by sonorous effects and figures of speech; it gives descriptions of specified scenes and events.

Thus, though the two genres differ widely in other respects, the epic subject-matter links kakawin with parwa. Of the five kakawins that nowadays in Bali stand highest in appreciation: Rāmāyaṇa, Bhārata-

3 See p. 59 , note 5.

4 In Java the term wayan parwa developed into w. purwa, which was understood as "shadow-play of olden times" and plays from Rāmãyaña and Mahābhārata were equally included in it. See H. N. van der Tuuk in TBG 25 (1879), p. 199 sq. and Van der Tuuk, Notes p. 49. Cf. Hazeu, Jav. tooneel 79 sq.

5 Actually in most texts the names of the parwas are not mentioned, but MS Kirtya 2189 gives a recension of the formula in which we find fifteen of them.

6 Lalampahan "Sutasoma", MS Kirtya 2290.

7 As a separate text MS Kirtya 1401. It is also found in MS Kirtya 1610, Dharma Pawayanan.

8 As MS Kirtya 2229 Bhagavān Uttaìka ka-utus ñarěrěh nitya-guṇ̣ala (The reverend Uttanka sent to find 'the eternal ear-rings'). It is the well-known tale of the Pausya-parvan in MBh. I, also to be found ĀdipOJ 111 sqq.

9 C. Hooykaas. The Old-Javanese Rāmāyana. An exemplary kakawin as to form and content. Verhandelingen KNAWL, NR dl. LXV No 1, Amsterdam, 1958. 
yuddha, Sutasoma, Arjunawiwāha and Bhomakāwya, the last four are frequently drawn upon for wayan parwa performances.

Moreover the repertoire of the wayan parwa, as well as that of the wayan Rāmāyana, was very much enriched by the activity of the dalañs themselves. They composed new plays that somehow, but often very loosely, were linked up with the cycles of Mahābhārata and Rāmāyana. These are what my informant I Gusti Ngurah Ktut Sangka styles "ḍalañs' tales" (Indonesian tjeritera padalangan). (Cf. § 17)

If we take the term parwa in a wide sense, including the tales from the kakawins and the dalan's' tales, our Cantakaparwa, as far as the narrative portions are concerned, is a parwa all right, both as to form and content, only the last chapter, Kapiparwa, belongs to the Rāmāyaṇa cycle.

\section{Linguistics; lexicography.}

But a large part of $\mathrm{CP}$ is of a different character altogether. The paragraphs on language and the lists of synonyms are closely akin to another class of writings, which may be comprised under the term $k r t a-b h \bar{a} s \bar{a}$ (lit. correct language). This kind of texts too may be as old as Hindu-Javanese civilization. With the interest in Indian myths and sagas, the interest in the language in which they were told naturally went hand in hand. That language, whether it was foreign Sanskrit or cultivated Old-Javanese of court-literature, was always far distant from the artless mother-tongue and the mastery of it had to be acquired by study. The Candakirana, an Old-Javanese treatise on several linguistic subjects (phonetics, metrics and lexicography), containing some quotations from the Sanskrit Amaramālā, probably originated in the time of Sailendra rule on Java $\left(7^{\text {th }}-9^{\text {th }}\right.$ cent. A.D. $){ }^{10}$ The first

10 Raden Saleh in the former century donated a palmleaf MS of this work to the Batavia Society of Arts and Letters, to which the Leyden Codd. Or. 4570 and 4571 (bequeathed by Van der Tuuk) go back. On the Jakarta MS see K. F. Holle, TBG XVI (1867), 461 sqq.; on the Leyden MSS Brandes, Beschr. III 202a sqq. and Juynboll, Suppl. Catal. I 170 sqq.; on the second half of CK (lexicographical; not included in CP) H. Kern, Un dictionnaire Sanskrit-Kavi, Actes VIième Congr. Internat. des Orientalistes III 2, Leyde, 1885 (= VG IX 273 sqq.) ; on the historical value of CK N. J. Krom, Over het Çiwaisme van Midden-Java, Mededeelingen KNAWL, LVIII B8, p. 203 sqq., also his Hindoe-Javaansche geschiedenis 2('s-Gravenhage, 1931), 12 and 150 sqq.

There has been some discussion about the original title and its meaning. Two places supply evidence in this question. (1) The beginning of the text as found in CP (it is missing in the MSS of CK itself) reads: Kirana wiyati candägni (obviously for candāgni) .... (Cf. p. 7, note 18). (2) The colophon 
half of it we find in CP (52a-63b). ${ }^{11}$

$\mathrm{CP}$ begins with a large lexicographical portion (till 33a), in which the words are arranged according to their meaning: names of gods come first, later on words for "fire" (5b), "wind" (6a), "mountain" (6b). There is a curious enumeration of men originating from different countries (8b): nara wrean Malayu/ purusya wrwain Cina/ nr wrean Parain/ na wwain Mumin/ jana wwain Bhuwon/ Bhutrawa wwan Klin/ etc. Van der Tuuk, who makes frequent use of $\mathrm{CP}$, says : "as a dictionary $\mathrm{CP}$, like the Javanese Dasanama, has little value, as it strains after subtle shades in words of the same meaning (examples under bělo, kirana and ambazean) and also contains imaginary etymologies (see under kaneka); most proper names in it are nearly unrecognizable (see under daronama and suntikanti) $; \ldots$ it explains also words that have been borrowed from other languages, not only Malay, Madurese and Sundanese (see ain), but also Moluccan (see under gora)." 12

\section{Manuscripts.}

The popularity of the text may be measured to a certain extent by the frequency of its copies. Though $\mathrm{CP}$ is not as well represented as the

of $\mathrm{CK}$ in the Leyden copies begins with Iti candatarana, but Krom, who used the Jakarta MS, says that it appears from that MS that the right name is Candakarana.

The following opinions were given by modern scholars. (1) In Brandes, Beschr. III 202a it is entitled Chandakirana, Candakirana, Candakirana. Gonda, Skt. in Indonesia, p. 125, note 39, mentions it under the title Candakirana (= the hot-rayed one, the sun). (2) On the strength of candatarana Van der Tuuk once (KBW I 573a, s.v. cantaka; the quotation in Brandes, Beschr. III. 205b may give rise to misunderstanding) suggested Chandahprakarana (= treatise of metrics). (3) Himansu Bhusan Sarkar (Journ. of the Greater India Soc. III 1, 1936, p. 108 sqq.) pointed to the mention, in a $14^{\text {th }}$ century inscription from Java, of Candravyulkarana, which might refer to Candragomin's Sanskrit grammar. C. Hooykaas, in his The Old-Javanese Rāmāyaṇa kakawin.... (Verhandelingen van het Koninklijk Instituut voor Taal-, Land- en Volkenkunde, dl. XVI) p. 17, then explained Canda-Kirana as an abridged form of Candravyākarana.

Van der Tuuk's conjecture Chandahprakarana seems to be built upon the supposition that CK is primarily a "treatise of metrics". Metrics however is only one of its subjects. As to Hooykaas' etymology, both in form and contents $\mathrm{CK}$ is widely divergent from Candragomin's work.

Since the opening words seem to point to Candakirana, since the vowel sign for $i$ is easily and often dropped (so that Candakarana in the Jakarta MS may stand for Candakirana), and since in Indian literature words for the great celestial luminaries are often considered suitable names for treatises and commentaries, it seems to me that Candakirana is indeed the original title.

11 See $\S 8$.

12 KBW I 574a sq., s.v. canțaka; quoted Brandes, Beschr. III 205b sq. 
classics of Old-Javanese literature, it is found in the University Library of Leiden in a considerable number of copies ; 13 and the Gedong Kirtya, Singaradja possesses a complete manuscript of it. The Faculty of Letters of the Udayana University, Denpasar has a Ketakaparwa. ${ }^{14}$ The manuscripts catalogued as "Tjantakaparwa" and "Tjatakaparwa" in the Museum Pusat of Djakarta, formerly Museum van het Koninklijk Bataviaasch Genootschap, ${ }^{15}$ are New-Javanese texts, different from the text discussed here. Neither these MSS, nor the Ketakaparwa of Denpasar have been taken into account here, but for a complete study of $\mathrm{CP}$ and its history they are of importance.

$\mathrm{Mr}$. Soegiarto, of the Oriental Institute of the Leiden University, has made typewritten copies of several MSS or parts of them, so as to give a text as complete as possible of $\mathrm{CP}$; these typescripts are

(1) Cod. 10.459, a copy of Cod. $4573=$ nr. 1190 in Brandes, Beschr. III 208 (this MS runs from the beginning of CP till D 24b);

(2) Cod. 10.460 , a copy of a part of $\mathrm{D}$ (see below), beginning where Cod. 4573 breaks off and ending at D 71a (where Cod. 4577 begins);

(3) Cod. 10.461, a copy of L (see below);

(4) a copy of D from $72 \mathrm{~b}$ till $79 \mathrm{a}$ to fill up a gap in $\mathrm{L}$;

(5) a copy of $\mathrm{G}$ (see below);

(6) Cod. 10.462, a copy of Cod. $4578=$ nr. 1198 in Brandes, Beschr. III 211.

Mr. Soegiarto's work has facilitated mine to a great extent. I have made good use of all his copies. Moreover I used the following MSS. D. Cod. Or. Leiden $4572=$ nr. 1189 in Brandes, Beschr. III 207b sq. $=$ nr. MCDL in Juynboll, Suppl. Catal. II 222. KBW as a rule refers to page numbers of this MS, when quoting from $\mathrm{CP}$ (though sometimes it refers to L). All references to $\mathrm{CP}$ in this study are therefore equally given in page numbers of this MS.

G. A paper MS lent to the Leiden University Library by Professor Berg (Bruikleen Berg nr. 71). It was copied in 1928 from a palm-leaf MS in the library of I Gusti Putu Djlantik, Singaradja (entered in the owner's catalogue as "A 38-44, doos 10"). Details concerning the palm-leaf MS and a table of contents on the first page of the copy. $\mathrm{G}$ gives the text of $\mathrm{CP}$ from the Wiwudaparwa till the end.

13 Brandes, Beschr. III 205a-211b. Juynboll. Suppl. Catal. II 219-222.

14 Box nr. 193, MS nr. 273. On Ketakaparwa see $\S 5$.

15 Koninklijk Bataviaasch Genootschap van Kunsten en Wetenschappen, Jaarboek 1933. (Bandoeng) p. 367 sq. 
K. A carbon copy, kindly lent to me by Dr. C. Hooykaas, of nr. 389 of the Gedong Kirtya, Singaradja. It contains the text of CP from beginning till the end. The Leiden University Library possesses an identical carbon copy, catalogued as Cod. Or. 9286.

L. Cod. Or. Leiden $4577=$ nr. 1197 in Brandes, Beschr. III 209b sqq. = nr. MCDLI in Juynboll, Suppl. Catal. II 222.

The MSS H and R came to my knowledge only when I had nearly finished this study, so that I could only make a very limited use of them. $\mathbf{H}$ is Cod. Or. Leiden 6435, a neatly written paper MS, formerly owned by Dr. G. A. J. Hazeu and copied from a MS of Dr. Brandes. It contains the whole $\mathrm{CP}$, only the beginning (one palm-leaf) is missing. $\mathbf{R}$, Cod. Or. Leiden 9845, is a carbon copy of Kirtya 1357b. It is entitled Kalakeya and contains the tale of Sutasoma from the beginning till 83b.

$\mathrm{D}, \mathrm{G}, \mathrm{K}, \mathrm{L}$ and $\mathrm{R}$ come from Bali. $\mathrm{H}$ is a copy of a MS from Bali. After the tale of Sutasoma comes a lacuna, which none of the MSS I have seen fills up, all of them continuing uja sah sakin sana. It probably has been caused by the loss of one palm-leaf. D, G and $H$ have the note: hilain satus kalih dasa. In D Van der Tuuk seems to have understood this in the sense of "120 pages are missing", as he gives the first page after the lacuna the number 207. More probable is the explanation he gives in L: "Een aanteekening zegt dat lontar 120 uitgevallen" (A note says that palm-leaf 120 has dropped out). $\mathrm{K}$ only says: iriki akeh kiran (here much is wanting). This lacuna is the clearest indication that all these MSS derive from one MS. For the rest also they evidently represent one uniform tradition.

$\mathrm{Mr}$. Soegiarto, while making his copies of $\mathrm{CP}$, now and then suggested emendations in brackets or in the margin. I have sometimes adopted these emendations, as will appear from the various readings.

\section{Identity and name.}

The text given by my MSS supports the authenticity of the title Cantakaparwa only. All MSS that have colophons give this name (variations in the first member Cantaka- and Cātaka-; in the second -prawa) and the term cantaka is found in the beginning of the text. I take the first member of the title to be an Old-Javanese form, with spontaneous nasalisation, ${ }^{16}$ of Sanskrit cātaka, the name of the well-

16 See Gonda. Skt. in Indonesia, p. 264. 
known bird Cuculus melanoleucus. 17 In this sense cantaka is used CP $11 \mathrm{~b}$ in an enumeration of vows: cantakabrata/ ikan cantaka aminta warsa/ "The cantaka-vow: the cantaka means to ask for rain." Manuscript $\mathrm{H}$ on its first page even gives the title of the book as Cantakaparwa, but this may be later "correction". It has Cantakaprawa in the colophon. Why the name of Cantaka was given to the text might perhaps appear from the opening, but its meaning is doubtful. It reads : awighnam astu/ nihan ikan sarasa/ dwijodah kowi (towi K) marutah/ nihan pakrti (v.l. prakrti) nikan cantaka/ bhațāra Manmatha/ akrti bhuwana/ My tentative translation: ".... Thus is the creation by the cantaka, god Manmatha, as he created the world", would imply that the cantaka is identical with Manmatha and that Manmatha here is the god-creator. ${ }^{18}$

However other names which may refer to this or a related text are handed down and mentioned in other sources.

(1) Ketakaparwa. Friederich, who was the first to make mention of $\mathrm{CP}, 19$ heard of this name as a title of the same text. As we have seen $(\S 4)$ a text under this title is known today; it is mentioned as the script for wayan performances. ${ }^{20}$

(2) Ce(n)takaparwa. Van der Tuuk 21 suggested Ketaka- to be related to cetaka, which he explains as "a designation for those tales that are not drawn from the ordinary kakawins, ${ }^{22}$ e.g. of Karna, who did not want to bow before Kuntī when her birthday was celebrated. This tale is said to be called Cetaka-Karna, but is unknown to me." 23

17 Cätaka in the title of a work in Càtakāsțaka. See H. von Ewald, Das Indische Gedicht vom Vogel Tschātaka, Zeitschr. f.d. Kunde des Morgenlandes, Bd. IV (1842), 366-376, and M. Winternitz, Gesch. d. ind. Lit. III 150.

18 Van der Tuuk (KBW IV 520b, s.v. Manmatha; where these and the following sentences are quoted) thinks this opening a support for a later explanation of Modern-Javanese Marmata (<Manmatha) by bațara Guru. On the identification of Kàma with Siva cf. J. J. Meyer, Trilogie altindischer Mächte und Feste der Vegetation (Zürich/Leipzig, 1937) I 36 and 40. Cf. also CP 52a (opening of $\mathrm{CK}$ ) : Kiraṇa vịaticandāgni dwijadakowimarutara (-marutsa $\mathrm{K}$ ) nāhan byakta pinakaśarīra bhațāra Mijzeala milwajanmāngawe bhuwana....

19 R. Friedrich. Voorloopig verslag van het eiland Bali (in VBG XXII, 1849) p. 16.

20 Kirtya MS 2233 is entitled Lampahan wayan Ketakaparwa. I have not seen it and further details are not available to me. But from the number in the catalogue I infer that it was acquired from Ubud (South Bali) April 10 ${ }^{\text {th }}, 1941$. The dalan of Padangtegal (a village in the immediate neighbourhood of and under one pěrběkĕl with Ubud) told me that for wayañ performances of Sutasoma Ketakaparwa is sometimes used.

21 KBW I 574a, s.v. cantaka.

22 Cf. the "dalan's' tales", $\S 2$.

23 KBW I 626a s.v. 
A wayan text 24 bears the title Kabegal(an) Arjuna. Pūrwa nin $\mathrm{Ce}(\mathrm{n})$ takaparwa (Arjuna robbed. The beginning of the $\mathrm{Ce}(\mathrm{n})$ takaparwa). I have not found this tale in my MSS of CP.

Obviously $\mathrm{CP}$ is a compilation. The Candakirana portion and other passages evidently have been taken unchanged from other texts and other parts are strung together so loosely that it is quite doubtful whether they were written at one time by one person. From such compilations paragraphs are as easily left out as new ones are inserted in them and it is only natural that they exist in various recensions, as many texts in Java and Bali indeed do. Therefore, for the time being, it will be wise to presume that the names Ketakaparwa and $C e(n)$ takaparwa designate texts that probably have much in common with our $\mathrm{CP}$, but are not necessarily identical with it.

\section{Author.}

$\mathrm{CP}$ does not tell anything about its author. And indeed, it can hardly have had an author in the strict sense, only a compiler.

Friederich (1.1.) says that it was made by Kawidasi "the follower of Byāsa". This seems to correspond to what Van der Tuuk heard: 25 "Kawidasa is supposed to be the name of the author of a treatise on Indian metres, which is incorporated into CP ..." So the tradition seems to be especially concerned with the Candakirana chapter. It should, I think, be taken for just a tradition, but, if ever an author actually bore the name of Kawidāsa or the lady's name (?) of Kawidāsī, it must have been a pen-name.

\section{Contents. Bhānzūtmajaparwa.}

We pass in review the contents at random. As we have seen, in the beginning lists of synonyms are given. The first part of the narrative portion (beginning 33a) is chiefly devoted to epic stories, in which the Pāṇawas and Korawas play a great part. Tales and series of synonyms alternate in this section.

On page $46 \mathrm{~b}$ begins the story of Karna 26 under the special heading

24 MS Kirtya 2234, acquired from Ubud (South Bali) April 10 $0^{\text {th }}, 1941$.

$25 \mathrm{KBW}$ II 208a, s.v. kazvi; quoted Brandes, Beschr. III 202a.

26 In main lines according to MBh I 104 and 126 sq. and $\bar{A}$ dip.OJ 110 sqq. and 134 sq., but different from that story in detail. The beginning till $47 \mathrm{a}$ is quoted KBW IV 575 (s.v. musuh). 
of Bhānwātmajaparwa: Patah (i.e. Pṛthā, Kuntī), while performing austerities as a pupil of the reverend Dhomya, becomes pregnant by Sürya and gives birth to Karna. She exposes the child on the Narmadā; it is found and brought up by Widata and Suketri, who give it the name of Rādheya. The Korawas (whose names are enumerated; cf. p. 59, note 4), on hearing of Rādheya's excellence in archery, invite him to their court, marry him to Suntikanti and make him king of Awanga. 27 When the Pānḍawas hear about this, Patah goes to Awanga, makes herself known as Karna's mother, but fails to win him over to the Pāndawas. Karṇa has seven sons and then abdicates to perform austerities. The Korawas Duryodhana (Kurupati), Jayadratha, Duhśāsana, Yuyutsu, Śakuni and Dhṛtarāṣtra also resort to spiritual teachers and practise asceticism.

This passage bears a close resemblance to the Korawāśrama (Krwś.), though there are a few divergencies, which may prove of some consequence. As in Krwś. Prajāpati does not grant the Korawas' wish that the Pāndawas may die, because "the Pạndawas are the content of the world." 28 The Bhānwātmajaparwa continues with the returning home of the Korawas mentioned above and the austerities of new characters, the last of which is Kuñjayakarna.

The story of this Kuñjayakarna is related more at length and is akin to the Buddhist legend of Kuñjarakarna edited by Kern. ${ }^{29}$ In both tales Kuñjaya-(respectively Kuñjara-)karṇa saves his friend Pūrṇawijaya from hell, but the reason why Pürnawijaya was condemned to hell is different. In CP he arouses the envy of Kāma, 30 who enters into him and makes him interfere with a widadari. Kuñjayakarna saves his friend by the power of his yoga and by wedamantra (Vedic formulas). No trace of Buddhism in this version of the tale.

27 The name of Karna's kingdom in MBh. and Adip.OJ is Ainga. But in OldJavanese kakawins it is Awanga. Cf. A. Teeuw, Het Bhomakāwya (Thesis Utrecht 1946). p. 240, s.v. Azvangapati. It occurs several times in Sut. k. Cf. p. 60 , notes 9 and 10 .

28 Pānḍawa iku paniisi nin jagat (49a). Cf. Krwś. 14.8 sq. : paran bĕcikane noraa Korazua Pāndazva, apan panisi nivi bhuzvana.

29 H. Kern. De legende van Kuñjarakarna volgens het oudst bekende HS met OJav. tekst, Ndl. vert. en Aantt. Verh. KNAWL NR III 3, Amsterdam, 1901 (= VG X 1 sqq.). On the strength of striking parallels in Europe C. Hooykaas conjectures that the tale must have an Indian origin. See his Een hypothese omtrent den oorsprong van het Oudjavaansche verhaal van Kuñjarakarna, TBG LXXI (1931), pp. 3-28, and The Buddhist legend of Kuñjarakarṇa and Pūrṇavijaya, Journ. of the Oriental Inst., Baroda, V (1955), pp. 95-98.

30 Rāma (KBW IV 63b, s.v. pürṇna) is a misprint. 
The following paragraph on the aji jahinain (a knowledge imparting perfect charm to the lady possessing it) (50ab) is partly identical with a passage in Krwś. ${ }^{31}$

\section{Candakirana.}

As we have seen, CP $52 \mathrm{a}-63 \mathrm{~b}$ is the first half of the Candakirana. This part of $\mathrm{CP}$ is of great importance for our knowledge of $\mathrm{CK}$, in the first place because it obviously supplies the text of the pages missing in the first half of the MS of CK itself $(1-5,8,10,11$ and 13). Further on some passages which we find in $\mathrm{CK}$ are missing in $\mathrm{CP}$ (among others the place where the Sailendra king Jitendra is mentioned).

\section{Wirendaparwa; Pralapitaparwa.}

From 64a onwards again epic stories. Some parts are given a special title: the Wiwudaparwa (wiwuda < Sanskrit vibudha, god) begins 73a, with the tale of the apsara (= gandharva) Angaraprana; 32 the Pralapitaparwa (75b sqq.) tells how the widows (enumerated) of the Korawas follow their husbands into death.

\section{Sutasoma.}

The episode beginning 78a is given the title Tatwa nira san Kälakeya, "Story of Kālakeya". Text and translation of the tale are given on pp. 20-57. It is in substance the story of Sutasoma as told by mpu Tantular in his kakawin Puruṣāda śānta.33

The jātaka of prince Sutasoma and the man-eater Kalmāṣapāda is well-known and has been told in many tongues and in various ways. ${ }^{\mathbf{3 4}}$

The main points recurring in most versions are (1) prince Sutasoma's meeting a brahman who is going to recite sententious verses for him; (2) his being carried off by a man-eater, who had vowed to sacrifice

31 Krwś. 134 sqq. Both passages quoted KBW IV 346b sqq., s.v. jahinan.

32 The name Angaraprana obviously goes back to Aingāraparna, the name of a gandharva king met by the Pāndavas (MBh. I 158 sq.), but the tale is different from the one told in $\mathrm{MBh}$.

33 The text with a Balinese and an Indonesian translation has been edited by I Gusti Bagus Sugriwa (Sutasoma .... Denpasar, 1959 ... 22 vols.).

34 Cf. K. Watanabe, The story of Kalmāșapāda and its evolution in Indian literature, Journ. Pali Text Soc. 1909, pp. 236 sqq. and H. Kern, Kalmāṣapāda en Sutasoma, Versl. en Meded. KNAWL 4 ${ }^{\circ}$ Reeks XI, Amsterdam, 1912 (= VG III 121 sqq.). 
a certain number of princes; (3) his being set free on parole in order to give the brahman a reward; (4) his return to the man-eater; and (5) the conversion of the man-eater and the liberation of the princes that had been captured before.

Tantular's version is essentially different from all others that have come down to us. ${ }^{35} \mathrm{We}$ mention only the most salient features. (1) The Buddha, who has descended to earth as Sutasoma, is identical with Rudra (as a form of śiwa), who has taken possession of Purușāda (the Man-eater; the name Kalmāṣapāda does not occur). Teachings on the identity of siwa and Buddha are an essential element in the text. (2) The character of the brahman coming to recite sententious verses is absent and hence Sutasoma, captured by the Man-eater, is not liberated on parole to acquit himself of his obligations towards the brahman. (3) While the plot is thus considerably changed, the form is also new : nowhere else, as far as we know, was the tale the subjectmatter for a kāvya complete in itself.

The Sutasoma kakawin seems always to have stood high in appreciation, especially for its profound religious teachings. It is staged in the wayan and it is again and again rendered into modern Balinese in the form of parikan (poems in Indonesian metres and in simple modern Balinese language). ${ }^{36}$

$\mathrm{CP}$ in outline agrees with Tantular. Apart from minor details the points of difference are: (1) CP gives more and often other genealogy. (2) The story of Daśabāhu winning his bride is rather different; it is told in the beginning and at much greater length. (3) Many persons have other names. Notwithstanding these divergencies - to which I shall come back in $\S 17$ - there is to my mind no doubt that the author of (this part of) CP knew and used Tantular's work. This, I think, is proved by striking agreement, even in the wording, in passages that are characteristic of the kakawin as a literary genre. Thus CP 82a: Amaingih parwata apinda danuja, atutuk guhālwa, amata silāputih, kady abhūsana limut ampakampak, aswara guruh pracanda, clearly follows Sut.k. XXXIV 4a sqq.: Gunuñ adbhutāsěmu mahäsura katěmu ri madhya nï wana/ matutuk guhālwa masilun kĕpuh aruhur

35 Cf. H. Kern, Over de vermenging van Çivaïsme en Buddhisme op Java naar aanleiding van het Oudjavaansch gedicht Sutasoma, Versl. en Meded. KNAWL

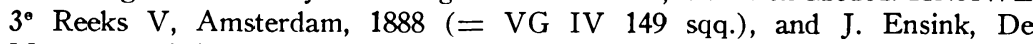
Menseneter bekeerd, HNF XXVI 220 sqq.

36 On parikan in general cf. C. Hooykaas, Indisch-Indonesische poëzie (Forum der Letteren III 1962), p. 225 and Hooykaas AT 99; on younger versions of Sutasoma and related texts Ensink, Sut. Onderzoek 104 sq. 


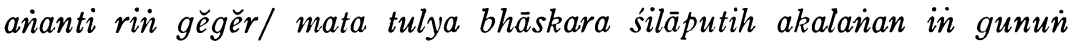
miděr/ masawit latāğè anurambat $i$ parainan ikaì mahāgiri// Bada-

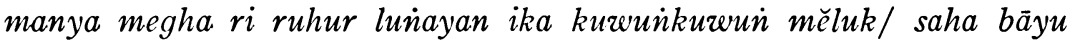
bajra kumusuh kadi laku nika rodrāgč́n galak/ And Sut.k. CXX 7a: Sakwehkweh para rājaputra maiirï lwir sarwapuspāněd̆ $\grave{n} /$ obviously was the model for CP 85b: dinulur in para ksatriya, kadi puspa manĕ $\breve{e} \check{n}$. Of course kakawin and parwa have much more in common, but in most cases the doubt subsists whether Tantular did not follow an older text, ${ }^{37}$ which then could have been CP's source as well. In the two given instances however, the kawi was on his own ground (the embellishments of language; alannkāra) and could not but be original; consequently the parwa here must derive from him. In $\S 17$ we shall see that, for the tale of Sutasoma, it probably also draws from another source.

\section{Cayabirama; Suprasena.}

After the lacuna signalized in $\S 4$ begins the story of Cayabirama and his conflict with the rākṣasa Gunatama, who later on becomes his ally. In this tale passing reference is made to Sutasoma and Daśabāhu, but apart from that I have found no trace of Buddhist tendency.

The next tale (from 219a onwards) is a prose version of the kakawin Wighnotsawa, 38 which has a strong analogy to the tale of Sutasoma. The hero, Suprasena, like Sutasoma, is a bodhisattwa, or rather an avatar of Buddha (pañjanman ira sain hyai Jina). According to Brandes 39 the tale as told in CP has been the source for the kakawin Bratasraya. The same tale seems to have been the subject-matter of a wayan tale, the lalakon Jinawikrama.40

\section{Kapiparwa.}

The last section of CP $(226 \mathrm{a}-240)$ tells of the marriages of bhaga-

37 That he had at least a starting-point in an older text we may gather from Sut. k. I 4: Pärreaprastāzéa nin parzearacana ginĕlar sanka rin Boddhakäwy'a/

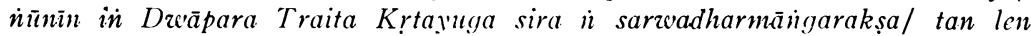
hyan Brahma Wiṣñ İšciara sira matěmah bhüpatīi martyaloka/ manke prāpta $\dot{n}$ Kali śri Jinapati manurun mātyana in Kāla mürkha// This tells us that Tantular had before him a text called Boddhakāwya, which dealt with the Buddha's coming down to earth in the Kaliyuga, though if, how and how detailed it related the story of Sutasoma we can only guess.

38 See Juynboll, Suppl. Catal. I, pp. 147-149 and Brandes, Beschr. III 343.

39 Beschr. I 201.

40 Cf. KBW IV 353a, s.v. Jina. 
wāns and widadaris, each couple having an offspring of numerous monkeys. ${ }^{41}$ Sugrīwa and Bāli, Hanumān and Rāma also enter the scene, and the text ends with Rāma adopting Sugrīwa as his brother and Hanumān as his son.

The table of contents of manuscript $G$ aptly entitles this chapter Kapiparwa. No doubt it is the same text which Friederich 19 mentions as a separate book, "which contains the history of Sugriwa, Hanumān and their ancestors in the dynasty of monkeys."

\section{Language.}

The language of $\mathrm{CP}$ is an Old-Javanese which, besides the old, shows many younger words and forms; e.g. aja (passim), orana (82a), norana (85b), kaì (passim), sakehe (85b), len (passim); anaturěna, aturĕna (86b), añatěrěna (213b), jĕnĕñĕna prabhu (220b), -a forms of -akĕn verbs; den- and depun- for the passive indicative (denpurugul, 79b; densěmbah, 82b; depunwalat, 80a; depunayunayun, 85b). I have not found any unmistakable Balinese words and forms.

Van der Tuuk $\mathbf{4 2}$ says: "Its [CP's] language is of very young date, as e.g. appears from words like sinhanabda in stead of sinhanäda and proper names like Srawainga [p. 60, note 9], which are much corrupted in it (see also e.g. under prth $\bar{a}[>$ Patah, cf. $\S 7]$ ), whereas even botched Arabic words occur (e.g. see pedah, bahit and purasani); besides it uses Chinese numerals (e.g. sam), and now and then a Chinese word (see camca); ...."

\section{Time of composition.}

It follows from what we have said in $\S 10$ that $\mathrm{CP}$ must have been compiled after the rule of king Hayam Wuruk (second half of the 14th cent. A.D.), whose contemporary mpu Tantular was. A terminus ante quem is found in the colophon of manuscript D:43 it gives the year 1758 saka $=1836$ A.D. As D is a copy of a palm-leaf MS from Klunkun, this obviously means that this Klunkun MS was completed in 1836.

41 Cf. Vālmiki Rāmāyaṇa, ed. G. H. Bhatt (Baroda 1960-) I 16, esp. Crit. App. 491*.

42 KBW I 573b sq., s.v. cantaka; quoted Brandes, Beschr. III 205b.

43 Quoted Brandes, Beschr. III 207b sq., nr. 1189. L.-Ch. Damais in his Études d' Épigraphie Indonésienne V (Bulletin de l' École Française d'ExtrêmeOrient XLIX), p. 138 has determined the equivalent in the Christian era as June $15^{\text {th }} 1836$. 
At this stage of research every attempt to determine the date more closely must imply a great deal of guessing. It seems probable that $\mathrm{CP}$ is posterior to Krwś.; not because the Bhānwātmajaparwa would be younger than Krwś. - which is not certain 44 - but because on the whole younger linguistic forms seem more frequent in CP. However Swellengrebel (40* sqq.) could not find a reliable terminus post quem for Krwś. Moreover, closer investigation of the material is required and one should bear in mind Swellengrebel's observation that one does not know whether certain linguistic features should be ascribed to difference in place or difference in time.

\section{Place.}

As we have seen, all my MSS originate from Bali. As to the question whether CP got its final shape there or in Java neither of the islands is ruled out. The verb forms in -ёna (see $\S 13 ; \mathrm{K}$ as a rule "corrects" them into -ana), I think, make it probable that certain component parts at least, came to Bali very lately. But even then the formation of $\mathrm{CP}$ as we know it now, could have been achieved in Bali.

\section{Use. Wayain.}

The contention at the beginning of this introduction, that the original aim of $\mathrm{CP}$ has been to impart all kind of knowledge needed for the study of ancient literature, will, it is hoped, have become plausible. It might now be asked for the use of what kind of people the book was intended and who actually made use of it.

It was pointed out in $\S 3$ that the language of the kakawins had to be learned, by aspirant poets as well as by readers. In Bali the production of Old-Javanese kakawins has never ceased; they are written even nowadays. Mabasan is the Balinese term for reading and discussing Old-Javanese literature. I Wajan Bhadra has described the activities of sěkaha babasan, literary clubs all over Bali, which come together regularly for that purpose. ${ }^{45} \mathrm{CP}$ may well have been composed with a view to the needs both of the kawi and his public.

44 Swellengrebel (p. 7*) supposes that CP [viz. the Bhānwātmajaparwa] goes back to a recension which differred considerably from the Korawāśrama we know.

45 I Wj. Bhadra, Het "Mabasan”. Bijlage Mededeelingen Kirtya Liefrinck-van der Tuuk. Soerabaia 1937; cf. Ensink, Sut. Onderzoek p. 105. For similar activities in Java cf. Th. Pigeaud, In Memoriam Professor Poerbatjaraka, BKI 122 (1966), p. 406. 
However one category of men by their profession must have had a special interest in texts like the $\mathrm{CP}$, viz. the dalanis of the wayan parwa.

Wayan no doubt is much older than CP. According to Pigeaud,46 it must have been performed in Java in the days of King Hayam Wuruk and probably was used for purposes of exorcism then, as it is nowadays both in Java and Bali. Wayan is the medium through which most people become acquainted with the tales from parwas and kakawins.

Different kinds of wayan literature are known from Java: a play (lakon) may be summarized in a short prose sketch, incorporated in the dalan's handbook (pakěm), or it may be written down in a fuller $\mathbf{4 7}$ form, which as a rule is designated by lakon. 48

In Bali it was and still is, not customary to confide the full text of a lakon (polite form: lampahan) to writing. The dalan knows the tale from the kakawin or another text, he knows the traditional ways to dramatize it for the wayan and, especially through the comic servants (panasar), puts in no small amount of improvised passages.

It may be only on the instigation of the German painter Walter Spies (who lived in Bali for thirteen years and took many initiatives in different fields of art) that full texts of lampahans were written down. In 1940 the Kirtya Liefrinck-van der Tuuk received a number of lampahans, all from the South-Balinese villages Bongkasa and Ubud and the dalan I Wajan Mendra soon afterwards contributed one or two lampahans in the North-Balinese style. Altogether the Gedong Kirtya now possesses sixteen lampahans. 49 According to Van der Tuuk, 50 who worked in North Bali, the Balinese dalan does not use a text like the pakěm of his Javanese colleague. In South Bali however, as we have seen, Ketakaparwa, which at least is akin to $\mathrm{CP}$, is used as a text for wayan plays. It does not seem too rash a supposition that $\mathrm{CP}$, if it was not written for the purpose, at least has served as a pakemm to Balinese dalanis. ${ }^{51}$ In the lexicographical chapters they could find a

46 Th. G. Th. Pigeaud, Java in the $14^{\text {th }}$ century, IV, 481 sq. and 516.

47 That is to say as complete as the text can be of a performance in which so much is left to improvisation.

48 Cf. Hazeu, Jav. tooneel 125-138; Tjan Tjoe Siem, Hoe Koeroepati zich zijn vrouw verwerft, Thesis Leiden 1938; and C. Hooykaas, Javaansche uitgaven van Volkslectuur, Djawa 12 (1932), p. 93 sqq.

49 MSS Kirtya 2189, 2209, 2229, 2231, 2232, 2233, 2234, 2235, 2235a, 2236, 2237a, 2243, 2244, 2247, 2249, 2290.

50 Van der Tuuk, Notes p. 49.

51 Brandes and Berg are inclined to look upon $\mathrm{CP}$ and similar texts as precursors of the Modern Javanese wayan texts. J. L. A. Brandes in the notes to 
large variety of Old-Javanese words, to use as the occasion demanded; the narrative parts could provide them with rough draughts for their performances; a passage in the panakșaman pawayanan included in Sut. 1 . (see $\S 2$; it actually refers to a Candrakirana) shows that dalans are concerned with linguistic speculations à la Candiakirana.

A few more facts testify to the close connection of $\mathrm{CP}$ with wayan. Two of the most important implements of the shadow theatre I have found mentioned in the lexicographical parts: for wayan (the leather puppets) the synonyms parante, pranagasta, rekacarma (rekadarma $\mathrm{K}$ ), ragacipta and ringit $\mathbf{5 2}$ are given; for kĕlir (the screen) wärana, tawen, bandhatinal and ciptanayana (sipta- K). ${ }^{53}$ In the "Korawāśrama" passage (see § 7) Dhṛtarāsttra gives instruction to Yudhișthira and mentions several kinds of spiritual teachers. ${ }^{54}$ Explaining the words mapurohita mangalam he says: Mapurohita iaran in guru; mangalam inaran in

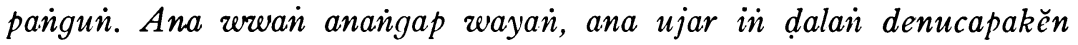
in parante. Parante inaran in ringit, anucapakĕn dharma aji kasampürnan in gātra, dentĕguhakĕn in hati. Guru pañguin ṅaranya. "Mapurohita means teacher; mangalam means operating-box. ${ }^{55}$ There is a man manipulating the wayan puppets and there are words of the puppeteer which he speaks through the parante. Parante means puppets; they teach the doctrine of the perfection of the body, a doctrine that is fixed in the heart. This (viz. the puppeteer) is the teacher in the operating-box."

In the tale of Suprasena we find a sentence Rahina tatas kamantyan, marěk $i$ sàn Datazirkrama,... "Thereupon day broke and he appeared

Pararaton .... uitgegeven en toegelicht door $-2^{\mathrm{c}}$ druk.... (VBG LXII, 1920), p. 209 sq.; C. C. Berg, Inleiding tot de studie van het Oud-Javaansch (Soerakarta, 1928), p. 131 sq.

52 Cf. KBW III 612a s.v. zuayain.

53 Cf. KBW II 239a s.v. kĕlir.

54 Cf. Krwś. 42. 19-30.

55 The set-up of the shadow-theatre as used at the royal courts of Java (the screen being visible to spectators from both sides) is also found in Bali. Cf. Mc Phee. Wajang koelit p. 3a and M. Covarrubias. Island of Bali (New York, several printings), p. 238 and picture opp. p. 236. But there is another form in which the dalan, together with his helpers and the musicians, sits in a small building, three walls of which are made of split bamboo, the screen forming the fourth. Consequently the spectators, sitting outside, only see the shadows on the screen, not the puppets themselves. This building is called parigun. It also occurs in Java and Kelantan. Cf. A. J. Resink-Wilkens. Eenige opmerkingen over de wajang-koelit voorstelling (Djawa 19/1939) p. 38b; and J. Cuisinier, Le théatre d'ombres à Kelantan (Paris, 2 1957), p. 57. 
before Datawikrama..." Rahina tatas kamantyan are the first words of Bhäratayuddha XXVI 1, which, as an introductory stanza, is used in many lampahans. 56 Probably the writer used the phrase because it was familiar to him from the wayan.

\section{Value for the history of literature.}

Works like $\mathrm{CP}$ as a rule do not meet with much appreciation at first sight. Their composition sometimes lacks harmony and the older sources often seem to be misuncierstood. Van der Tuuk (e.g. see $\S \S 3$ and 13) stressed what he considered the weak points of the text: mangling of words and names, changing of names, misunderstanding or misrepresenting older tradition. Yet, as far as the second and third point are concerned, it must be questioned whether lack of understanding or negligence should be made to account for all the obvious divergencies between older tradition and the recapitulation. In many cases we do not know the model the author had before him or we are not sure about it, so that we cannot state the case clearly. Moreover we should bear in mind that the writer was not bound to the same code of historical and philological fidelity as we are and may have had his reasons (religious, political or otherwise) to alter the tradition to some extent. For example we can well understand an Indonesian author (Tantular or a predecessor) giving the originally Buddhist legend of Sutasoma a Śiwaite-Buddhist tendency.

The tale of Sutasoma affords a relatively firm footing for dealing with these questions, as we have seen that the CP author knew Tantular's kakawin, though he may, and indeed is very likely to, have known another recension as well. We will therefore again consider the relation between kakawin and parwa.

It can easily be granted that sometimes misunderstanding is the cause of a certain difference. Thus Kaingala (CP 87a) should be Aingala; cf. Sut.k. XCVII 11b janakängala. 57 In the list of kings offered to Kālaweśma (CP 85a) figure many lords who in the kakawin (CXII) are said to be allied to Sutasoma and at that moment at the court of Hastina: prabhu rï Lĕ̀ika, Aruṇa, Sutāgra, Dasapata (<Daśapati),

56 Cf. Mc Phee. Wajang koelit pp. 32a and 33b.

57 Other changes are signalized in the notes to the translation pp. 59 sqq. 
Gameka (<Gameki), Padmaketu, Jamañga (<Jyāmaga), Subadĕtta. This in all probability must be ascribed to the parwa author, who obviously had to scrape together his hundred kings from every nook and cranny. $\mathrm{He}$ is, as far as known, the only one to give such a list. In our text it numbers only 97 names.

However, to my mind, it is not probable that error or negligence played an essential part in the more important differences (cf. § 10).

Daśabāhu, in both the kakawin and the parwa, is the third character in importance - after Sutasoma and Purușāda - and Sutasoma's elder cousin, brother-in-law and devoted ally; a formidable fighter against the demons. He is an incarnation of Brahmā (Prajāpati, Dhātṛ) and therefore his role seems to be essential. (In the tale of Suprasena Datawikrama, Suprasena's elder cousin, is also an incarnation of Brahmā.) In CP his expedition to conquer his bride is an important element in the tale. Tantular gives a somewhat different story, which he tells very shortly (cf. page 60, note 10 .), compared with CP. It does not seem probable that it was the author of (this part of) $\mathrm{CP}$ who worked out this episode. The general trend of his work rather was to renarrate and eventually condense the subject-matter as he knew it from tradition. But the hero winning the hand of a princess is a favourite theme for a lampahan and this story must have made a very good show on the wayan screen. It is very likely that we have before us a summary of a lampahan, which probably must be reckoned among the "dalans' tales" (see $\S 2$ ). It is an open question whether the author of this tale took his theme from Tantular's kakawin or from another source.

As to the differences in the names, especially of Sutasoma's ancestry, these are so glaring that they can hardly be ascribed to error. For instance, in naming Sutasoma's father Candranātha the parwa author cannot have meant to follow Tantular, who gives this character the name of Mahāketu. The same holds good for the names of the ancestors of Sutasoma's mother and Daśabāhu. If the author did not find these names in some source (other than Tantular), he may well have had his reasons for the changes. Especially the linking up of Sutasoma's family with the Panndawas, in a sphere where the Panndawas and the Korawas played such an important part ("content of the world", $\S 7$ ), is very likely not an idle change (see Tale of Sutasoma $\mathrm{CP} 78 \mathrm{~b}$ and p. 59, note 5.). Moreover we must be aware of the fact that Tantular, 
as a court poet, may have had occasion to rename his characters quite as well, and that CP might continue an older tradition.

Thus, far from being a mere compilation of stories and other material which we already know better from elsewhere, the Cantakaparwa, though apparently young, may prove a valuable source for our knowledge of Old-Javanese literature and its history. It certainly is a document of the vivid interest later generations entertained for that literature. 


\section{THE TALE OF S T A SOMA}

$\operatorname{TEXT}(\mathrm{CP} 78 \mathrm{a}-87 \mathrm{~b})$

78a Puniki 1 tatwa nira sañ Kālakeya. Sañ Kālakeya analap anak sañ Mālyawān wuruju, rākṣasī naran dewī Anīlā; maputra kakalih, paḍa kakun, ṅaran sañ Hiranya, san Kaśipu. Sañ Hiranya mapriyā anak ${ }^{2}$ ira sañ Khara, rākṣasĩ naran sañ Sumina ; 3 maputra lilima, paḍa kakun, naaran sań Solara, sañ Śakuni, san̉ Duṣkṛta, Mānakañśa, sañ Cora. Sañ Śakuni marabi wĕka nira sañ Duṣkṛta, rākṣasĩ naran Ratmaka; masuta sasiki, naran sañ Sudasa. San̉ Sudasa marabi rākșasī naran sañ Wiratma, anak ira sañ Kruddhākṣa; maputra sasiki, jalu, mawulu dom wěsi, naran san̉ Puruṣāda, macarma loha, titis ira bhațāra Paśupati, mahyun 4 amubura ń jagat, sinawita 5 de nin danuja, bhūta, piśāca, khagawaktra, hastindrawaktra, ādinya: Jayawiṣnu, Wimona, ${ }^{6}$ Indrabajra, Kubhūmi, Sumala, Kumala, ${ }^{7}$ Pralĕmba, Duloma, Durmendragra, ${ }^{8}$ Bajra, Kaluṣa, Dhūmawadwa, Subhanga, Ketu, Durlakșaṇa, taneh yan wilanèn kwehnya.

Biṣa nira san̉ Sudasātmaja 9 denyārěp amahaywa ṅ jagat, mañka 10

78b cinidra rin bhoga. / Dinaharan ganan hares nankěn dina, manka ta kahěrěb tanian in aolah 11 ganan, katut 12 rahnya rin 13 hares, milu kaolah, winirāman 14 de 15 sañ Purosada. Añrasa biṣa, tinakonan punan 16 aolah 11 : "Paran raragine 17 denta olah biṣa rasane awuduk 18 amanis?" Sumahur punan abětẹ̆k: "Singih, tañan in patik 19 Bhațāra kahěrěb; katut rah, kakěla ${ }^{20}$ pukulun." Mañka añasa ṅ bhūtarāja, ${ }^{21}$ wĕruh yen enak iwak won. Mankwa tiněwĕk punañ abĕțěk, inolah, pinanan, arasa 22 wuduk amanis. Mańka manalap janma lanan wadon,

\footnotetext{
1 Punika D. In $\mathrm{L}$ the beginning till $79 \mathrm{a} n a$ awayah rumājaputra is missing.

2 mapriya rin anak

3 Musina G.

4 ahyun D.

5 sinawitan G.

6 Wimona om. G.

7 Kumala om. K.
}

8 Dumendagra D, Durmedagra K.

9 Sudasa DK.

10 amayu jagat mankza $\mathrm{G}$.

11 anolah $\mathrm{K}$.

12 katutut G.

$13 \operatorname{nin} \mathrm{K}$.

14 winirama G, KBW I 112b, s.v. hares: winiraman (zeinirasan?).

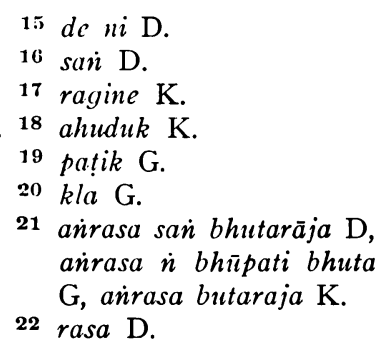




\title{
THE TALE OF S T A SOMA
}

\author{
TRANSLATION
}

78a This is the story of Kālakeya. Kālakeya took to wife the youngest child of Mālyawān, a rākṣasī called princess Anīlā; he had two children, both boys, named Hiranya and Kaśipu. Hiranya wedded a child of Khara, a rākșasī called Sumina, he had five children, all boys, whose names were Solara, Śakuni, Duṣkṛta, Mānakañśa and Cora. ${ }^{1}$ Śakuni married the daughter of Duṣkṛta, a rākṣasī called Ratmaka; he had one son, who was given the name of Sudasa. Sudasa married a rākșasi called Wiratma, a daughter of Kruddhākșa; he had one child, a son named Purusaanda. The hairs on the body of this son were iron needles and he had an iron skin. ${ }^{2} \mathrm{He}$ was possessed by ${ }^{24}$ god Paśupati, who wished to destroy the world. He was obeyed by danujas, bhūtas, piśācas, demons with a bird's face, demons with an elephant's face and the like: Jayawiṣnu, Wimona, Indrabajra, Kubhūmi, Sumala, Kumala, Pralĕmba, Duloma, Durmendagra, Bajra, Kaluṣa, Dhūmawadwa, Subhanga, Ketu, Durlakșana, it would be too long to count their number.

Powerful was Sudasa's son as he wished to bring the world to

$78 \mathrm{~b}$ prosperity, but then he was deceived by way of his food. A dish of fresh banana stalks was served to him every day. Now the person who cooked the food cut his hand, the blood ran upon the stalks, it was cooked together with them, and Purosada enjoyed it. ${ }^{3} \mathrm{He}$ found that its taste was racy, and asked the cook: "What did you put into this, that it tastes so racy, rich, and sweet?" And the cook answered: "Indeed, the hand of Your Majesty's servant was cut, the blood ran into it, and I cooked it, my lord." Then the king of the bhūtas tasted it [again] and learned that men's flesh is nice. And so he stabbed the cook, cooked and ate him, and found his taste rich and sweet. Then 
pinañan. Mañke kinen kan 23 bala danuja mañalap janma. Man்kwa ta kawěs tañ mānuṣa, pạ̣a mañili, muñsi 24 deśa nagara.

Tucapa śeșa nin Korawa pějah, kantun kakalih,25 naran san Wirabāhu, san் Sranama. San் Sranama matakut i 26 sañ Pāṇdawa, manunini wukir Wanawatī, maguru 27 rin bhagawān Atri, pinaraban bhagawān Sumitra. Sañ Wĩrabāhu asěnětan rin sramawana; tĕlas in̉ 28 Korawa.

Saǹ Pāṇ ̣awa anaděg 29 ratu rin 30 Hastina, manulah sāma dāna 31 rin wadwa, paḍa lulut. Masuta 32 kalih, paḍa kakun, naran san் Maya, san் Ketu. San Maya tan ahyun in kawīryan, maguru rin bhagawān Sumitra, liningan bhagawān Keśawa. Sañ Ketu marabi ātmaja nira maraja 33 Bhīmabala, manaran Smarawanā; maputra kakalih, jalu san் atuha, naran san் Candrasin̄ha, san் anom istri, naaran sañ Prajādharīi.34 Saǹ Candrasinha mapriyā ātmaja nira maraja Satradharma, 35 ñaran dewī Rewatī. Dewī Prajādharī inalap de sañ Candranātha, suta nira maraja Rukmaratha, suta nira san் Somadatta. ${ }^{36}$

Dewì Rewatī tan papuputra, mañka mohita de 37 nin manah piyambĕk. 38 Lin sañ nātha: "Yayi, punapa 39 karan ira mohita? Manawi de nin kawula, manawi de ni pun kaka?" Lin sañ dewī: "Kaka aji, punapi doṣa ni pun yen bĕndwa rin kawula, i Pāduka Bhațāra mapan boya, kewala de nin sraya piyamběk." Lin sañ prabhu 40: "De nin punapi ta, yayi ?" Lin san dewī: "De nin manira tan pasusuta.41 Yen lunsur Pāduka Bhațāra lawan pun 42 yayi, sapa sira gumantyanana pura puniki 43 ?" Mañkwa amicāren 44 buddhi sañ nātha; mañkwa ta ahyun 45 anhyañ 46 yen anaktya, 47 anẹdaha 48 putra rin hyan் kan்

79a rumakșen் 49 kuța : / Yen tan pantuka, saĕṅgeněngenan manira pějaha,50 sukha manira." Lin sañ Rewatī 51 : "Yen mañkana, pun yayi saparan Pāduka Bhatāana, pađ̣ĕma huripa." Lin sañ nātha: "Sakarsa nira yayi." Man̉kwa kulĕm lunha san் prabhu manilib pamrĕm in wwan் in purī. Prāpten் kānanāgĕn் ; ananakti, tan pantuk. Man̉kwa amicāra riǹ buddhi,

\footnotetext{
$23 \tan \mathrm{D}$.

24 ainusi $\mathrm{K}$.

25 kantun kakalih om. K.

26 sain Wïrabāhu saì Sranāma matakut $i \mathrm{DGK}$.

27 Manawati, gumuru K.

28 tělasan G.

29 mañadĕg $\mathrm{G}$.

30 rin om. G.

31 madhana $\mathrm{G}$.

32 lulut sain wirabahu masuta G.

33 sain $\mathrm{G}$.
}

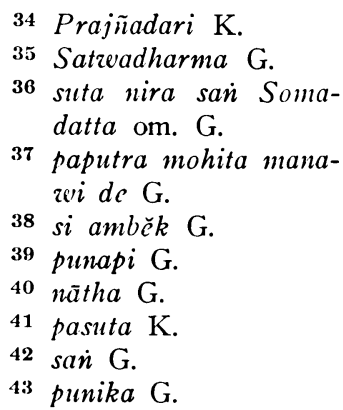


he caught men and women and ate them. Then the danuja troops were ordered to catch men. And so the people became afraid; they all fled, taking refuge in villages and cities.

Let us now tell of those Korawas that escaped death. Two were left, their names were Wīrabāhu and Sranama.4 Sranama was afraid of Pāndawa, he took refuge on mount Wanawati and became a pupil of the reverend Atri under the name of Sumitra. Wirabāhu hid himself in a hermitage in the woods; that was the end of the Korawas.

Pāndawa ruled as king of Hastina and was kind and liberal towards his subjects, so that they all were devoted to him. He had two children, both boys, whose names were Maya and Ketu. Maya did not aspire to a life as a king, he became a pupil of the reverend Sumitra, under the religious name of the reverend Keśawa. Ketu married the daughter of king Bhīmabala, called Smarawanā; he had two children, the elder one a boy named Candrasinha, the younger one a girl named Prajādharī. Candrasinha wedded a daughter of king Satradharma, called princess Rewatī. Princess Prajādharī was taken to wife by Candranātha, a son of king Rukmaratha, a son of Somadatta. ${ }^{5}$

Queen Rewatĩ did not have any children, so she became sad in her heart. The king asked her: "My dear, why are you sad? Did the servants give you cause for it, or was it I?" The queen answered: "My lord and king, what is the servants' fault that I should be angry with them! And of course I am not angry with Your Majesty; it is only on account of a want I feel myself that I am sad." The king asked: "But why do you feel a want, my dear?" And the queen answered: "Because I do not get any children. When Your Majesty and I have passed away, who will succeed to the throne?" Now the king considered in his heart, and then he decided to keep a religious observance and 79a pray for a son to the god who guarded the city: "If I do not get a child, then, no doubt, I shall willingly seek death." Rewati said: "If that is the case, I shall follow Your Majesty, wherever Your Majesty goes, albeit into death." And the king answered: "As it pleases you, my dear." Now in the night the king went forth, stealthily, while the people of the court were asleep. They came to a large forest; there they prayed, but obtained no result. Then they considered in their hearts, 
mara en 52 Pantarabhūmi, palaga nin Korawa lawan Pāṇḍawa; śīghra prāpterika. Ginilagila de nin banaspati, bhūta, děnèn, curumani; mūrcchita dewī Rewatì rin kisyapwan san kaka; tan lĕga manah sañ prabhu. Bawis tumurun bhațāra Caturmukha, lin ira: "Paran ta denta palaku, sankanta mara nike, tan takut in banaspati, curumani? Paran ta denta pinta? Mapan kita wibhuh in artha, kanaka, ratna." Lin san nātha: "Pukulun, tan panĕda punapipunapi, kewala anĕḍa puputra, yen jalu, kań rumakșaheñ pura, yen wadon, dadya panisi 53 nin purī." Lin sań hyan Prajāpati: "Iya, katěkan karsanta iku. Yen kakun, aranana Daśabāhu, ${ }^{54}$ yen istri, aranana 55 Puṣpawatî." Sawega manabhiwāda sañ nātha, samby 56 anẹḍa amisingih; mur sañ hyan Dhātṛ. Mantuk san prabhu iñĕmban sañ patnī; śīghra prāpten purī; karipan aguliñ akarwan ulěs.

Tan hopĕn in lawasnya; mangarbhin̄ī 57 sañ dewī, bawis maputra jalu, 58 mabhuja sadaśa, mawarna danuja. Lumihat in putra, sañ Rewatī malayu; geger sapurī; gadgada sañ prabhu, lumihat in putra; ahewa, moněk in 59 san hyan் Dhātṛ de nin tan tuhu. Ya ta makon 60 añundana sira patih, kinen an̉hañuta rin putra 61 salah rūpa. Pintu kinuñci; kawula tan sinuñ 62 umun. Śīghra pinuṇụtut pāka punika, mukṣah inalap 63 de sañ hyañ Dhātṛ. Liṇdu, hudan kṣaṇika; śīghra tinẹdunakěn de san hyan் Prajāpati 64 tekan waraṇa, awayah, rumājaputra, pragiwaka, sulakṣaṇa, śakti kadi san hyan Prajāpati; těkānabhiwāda ri san Candrasinha. Kagyat san nātha de nin àtmaja agun tan in ulah; mojar yen sakin sañ hyañ Dhātṛ naran Daśabāhu. Ḍěnèr 65 sañ apatih Jayawirota; sinamohakĕn 66 in mantri kabeh yen kinon amor in ratu taruṇa, biniseka 67 sañ Daśabāhu. Mañka manulah sāma dāna, tan apilih jana, kinalulutan 68 in bala.

Tucapa 69 sañ prabhu masuta malih, istri antyanta hajěn ira, kadi sañ Rājalakșmī, pamulu kadi candra pūrṇa, inaran sañ Puṣpawatī; iña nira naran Jayasurāga, 70 wěka nin kasiman, cakșu in paramakawi.

Tucapa hana ratu titiga, ${ }^{71}$ sanak, ātmaja nira maraja Brajakala, san atuha maraja Koṣa, prabhu rin Magadha, arinya naran maraja Siwanda,

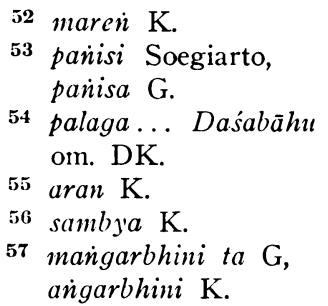

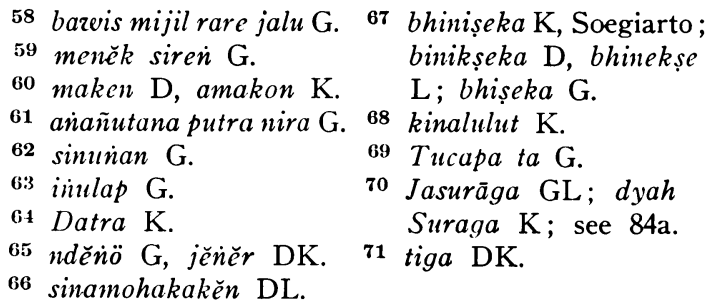


they went to Pantarabhūmi, the place where the Korawas and Pāndawas fought their battle; soon they arrived there. They were frightened by tree-spirits, bhūtas, děněns and curumanis; queen Rewatī fainted in the lap of her husband, but the king did not give way. Then god Caturmukha descended and asked: "What is your request, that you came here, not afraid of tree-spirits and curumanis? What is your asking? For you are rich in goods, gold and jewels." The king answered: "My lord, I do not ask anything, I only ask to have a child, if it be a boy, to guard the city, if it be a girl, to be heiress to the throne." Prajāpati said: "Well, your wish is granted. If the child be a boy, name him Daśabāhu; if it be a girl, name her Puspawatī." Quickly the king thanked the god and accepted his words obediently; god Dhātr disappeared. The king went home, accompanied by his consort; soon they arrived in the palace; as they were sleepy, they lay down together.

In short, the queen became pregnant and afterwards gave birth to a son, who had ten arms and looked like a danuja. When Rewati saw her son, she fled; all the palace was appalled; the king stammered, when he saw his son, he felt aversion and his trust in god Dhātr was shaken, as the god seemed not to remain true to his word. So he had the prime minister summoned and ordered him to do away with this misshapen son. The door was closed and the servants were not allowed to tell anything. But suddenly the babe was lifted up and disappeared as it was taken by god Dhātr. The earth trembled and rain fell and immediately afterwards the child was brought down by god Prajāpati, fullgrown, of princely bearing, intelligent, faultless, powerful like god Prajāpati; 6 and, lo, he saluted Candrasinha. The king was amazed that his son was so extraordinarily big; he related that god Dhātr had destined this son to bear the name of Daśabāhu. The prime minister Jayawirota heard this; he summoned all the ministers and told them that they should wait upon the prince royal as he was consecrated under the name of Daśabāhu. And the prince was kind and liberal, without preference for anybody, the object of the devotion of his men.

Let us now relate how the king again had a child, a girl of exceeding beauty, like Rājalakșmī; her complexion was like the full moon. She was given the name of Puspawati, 7 and she had a nurse called Jayasurāga, a daughter of a kasiman, 8 the very best of excellent poets.

Then let us tell of three kings, who were brothers, sons of king Brajakala ; $8^{\mathrm{a}}$ the eldest was king Koṣa, ruler of Magadha, his younger 
79b nātha rin Srawañga, wuru/ju naran Suśrawa, nātha rin Kalinga. Mañkwa maraja Koṣa mahyun arabi, malih pajěn lawan putrī $71^{*}$ nira sañ nāthen Mālawa naaran maraja Sindhurāja; putrī ṅaran sañ Priyawatī ; samāpta pajĕñ, těběn in kārya. Mañrěnö sañ Daśabāhu, amiweka lawan bhrtya, mantri kabeh, lin ira: "Añrunu kita niștha, madhya, uttamen apriyā." Hatur ira patih Jayawirota: "Singih, niṣtha wwan pinarabekěn 72 de nin patnī, madhya wwaǹ pinakramakěn 73 de nin yayah, rena, uttama wwan yen arabi anuku rin pran, atoh 74 jīwa, atawìn curik, ${ }^{75}$ līlāwīrya, santaki; 76 wiśobhitapriya 77 naran in ratu daridra amangih wīrya nin priyā." Sampun magunita lawan sira patih, 78 ahyun mañkat sañ Daśabāhu, tinanguhan mārdawa. Śīghra mamwit in san prabhu: "Pukulun, pun anak ahyun ḍatěnen 79 Mālawa, ahyun an̉ambila putrī nira sañ nāthen Mālawa." Lin ira sañ Candrasinha: "Kaki Daśabāhu, sampun! Yen sira harěp arabyāmilihana 81 anak in ratu." Lin san̉ Daśabāhu: "Asuna, mboyaa, ${ }^{82}$ pun anak mañkat." Śīghra luniha mañkat san Daśabāhu mungw in ratha, saha balakrama; sira patih Jayawirota hanen hasti. Tan makaḍat prāpten Mālawa. Sira patih amoṇḍok in alunalun, apajĕg 83 wanuntur, pasěk agěn sěsěk de nin wadwa Kāśīpati. Sañ Daśabāhu mareñ purī 84 sañ rājaputrī, kapangih inahesan. Bawis pinundut maren pawaranan, pinriyambada de san Dhātrātmaja. Geger in dalĕm, paḍa malayu, matur in sañ prabhu yen putrī nira winalat de san Kāśīpura. Kepwan sañ prabhu, magunĕm lawan yodha, mantri de nin ratu taruna sañ Koṣa arabi, anhur san nāthen Kāśīpati ratu taruṇa. Jïrṇa manah sañ prabhu. śīghra ḍatañ 85 utusan ira sań Koṣa anrěgaken 86 i 87 sañ nātha: "Ḍatan் 85 mantu Pāduka Bhatāra. Punĕndi gen 88 in pipinanan ranak Pāduka Bhațāra ?" Lin sañ prabhu rin utusan: "Anu, matur in kaki prabhu yen san rājaputrī denpurugul dene 89 san nāthen Kāśīpati. Mañke haneñ purī akalihan." Śīghra malajěn punañ utusan, prāpta rin sañ Koṣa, matur:

80a "Pukulu/n, punapi 90 karsa nin tuhan? San rājakanyā depunwalat 91 dene san Kāśīrājaputra, naran sañ Daśabāhu. Marike hanen dalěm.

\footnotetext{
${ }^{71}$ putra D.

72 pinarabekakĕn DL.

73 pinakramakakěn D.

74 atoh DGK, Soegiarto; ajoh $\mathrm{L}$.

77 wisonitapriya GL,

78 mapatih $\mathrm{G}$.

79 datĕn in $\mathrm{K}$.

81 arabhihahana L.

75 atawin curik om. K.

82 boyaha K.

76 santaka G.

83 papajĕg G.
}

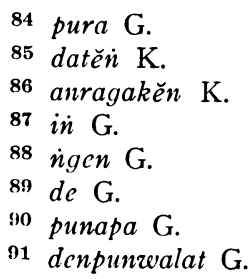


brother was called king Siwanda, ruler of Srawanga, ${ }^{9}$ the youngest $79 \mathrm{~b}$ was called Suśrawa, king of Kalinga. Now king Koṣa wished to marry and was already betrothed to the daughter of the king of Mālawa, whose name was king Sindhurāja; the princess was called Priyawatī; the betrothal was already contracted and the day of the marriage appointed.10 Daśabāhu heard this, he deliberated with all the courtiers and ministers and said: "We have heard that there is a basest, a mediocre and an excellent category of the men who marry." The prime minister answered: "Yes, the basest man is made to marry by his wife, the mediocre man is wedded by his father and mother, but excellent is the man that marries through his conquest in war - thus staking his life - even with the dagger alone, a hero at play ...; lover of beauty(?) is the name of the wise $10^{n}$ king that marries the excellence of his bride(?)." After he had deliberated with the prime minister, Daśabāhu wanted to go, though he was dissuaded from it courteously. Immediately he took leave of the king: "My lord, your son wishes to go to Mālawa, he wishes to take the daughter of the king of Mālawa." Candrasinha said: "My dear Daśabāhu, do not do so! If you want to marry, you should choose [another] daughter of a king." But Daśabāhu answered: "Whether you allow me or not, your son goes." Quickly Daśabāhu departed - standing in his chariot - together with his troops; the prime minister Jayawirota rode on the back of an elephant. Without delay they reached Mālawa. The prime minister camped in the outer courtyard, rows of soldiers sat in the main courtyard, the hosts of the men of Kāsís's lord were large and densely crowded. Daśabāhu went inside the apartments of the princess and found her as she was being attired. Immediately Dhātṛ's son 6 lifted her up and took her to the bridal room, where he won her over with sweet words. The people in the palace were alarmed, they all fled and informed the king that his daughter was conquered by Kāśipura. The king was embarrassed, he deliberated with his officers and ministers that the prince royal Koṣa was the lawful bridegroom, but that the king of Kāśi was rather preferable as prince royal. The king's heart was cheered. Soon afterwards came an envoy of Koṣa to urge the king: "Your Majesty's son-in-law has come. Which place is reserved for the allies of Your Majesty's son?" The king answered the envoy: "Well, tell the king that the princess has been taken by the king of Kāsis. Now they are together in the palace." Immediately the envoy hastened back; he came

80a to Koṣa and said: "My lord, I am at your service. The princess has been taken forcibly by the son of the king of Kāsiî, called Daśabāhu. 
Inanděgakěn tekan babaktan." Sawega marĕk in 92 maratuwa 93 maraja Koṣa mañabhiwāda rin maratuwa 94 : "Punapi 95 karan in 96 wande ?" Lin sañ Mālawarāja: "Kaki prabhu, kami tan wruh pinañkanipun san nāthen Kāśípati mara ṅke. Mañkin 97 hanen dalěm pawaranan." Lin sań Koṣa: "Sapa kan̉ aweh mārga ?" Lin san Mālawapati : "Tan wikan mārganipun." Bawis mamwit 98 sañ Magadharāja, prāpteñ 99 hen nin purī,100 sinunisun de 101 sañ Srawangarāja, sañ Kalingapati, mwan் pipinañan pituwĕlas, ṅaran maraja Cārudeṣna, Bajrānala, Nīlabāhu, Wikarṇa, Sulamañru, śūlabajra,102 Wìroddhata, Sin̄hawadana, Braja, Wiroșa, Sutikṣna, Pragupta, Prawasta, Naladeka, 103 Supadira, Praduharsa,104 Nisati. Paḍa rabdha manah ira saha bala, paḍa yatna, sampun kajĕñan ${ }^{105}$ yen rumusakeñ kuṭa Mālawa. Kinulilinan, sampun akrama pěnuh,106 mṛdanga kaya guntur gumuruh awurahan. Kewran san̉ nāthen Mālawa; pinarĕk in para mantri. Karsa nira sañ prabhu manuundaña ri 107 sañ Daśabāhu. Tuṣtāmbĕk in para sawita, śïghra marĕk ri sañ Daśabāhu, lin nira: "Kaki prabhu, punapi 108 karsa nira? Maraja Koṣa ahyun añrěwěk 109 kuṭa saha warga, bala pipinañanipun, paḍānayĕni, amrih pějaha nira." Sumahur sañ Dhātrātmaja: "Pukulun, sampun walan hati Pāduka Bhațāra. Woǹ Mālawa sampun wontěn tumut, pạ̣a rumakșahen pura." śïghra mijil saha bala mungew in ratha san Dhātṛputra; san apatih Jayawirota saha bhṛtya, wāhana sawega mawantah, kadi gubar mapagut, kady alun pinapag rin anila. śawa atumpuk kadi bukit. Maraja Koṣa, Siwanda, san Kalingapati amapag laga sañ Dhātrātmaja; kasoran, kapusus 110 rěbah saha bala. Tumuluy mapulih susuruhan pituwělas; maraja Cārudeșna pẹjah.

80b Mapulih sañ Bajrā/nala, Nīlabāhu; pějah tan pañựili.111 Mapulih maraja Wikarna, Sulamañu; 112 mati saha turanga,113 bala. Apulih maraja Śūlabajra, Wīroddhata, Sin̉hawadana, Braja, Wiroṣa, Sutīiṣna ; paḍa pějah de sañ Dhātrputra. Mapulih san̉ Pragupta,114 Prawasta, Naladeka; 103 pinapag de san mapatih; pějah tan panuựili. Apulih sañ Supadira, Praduharsa,115 Nisati; kinĕmbalan 116 sira patih kadi potaghṛsți, putuñ panahnya de san Praduharsa, pinarěpěkan de san

92 in om. L.

93 maratuha $\mathrm{G}$, ra matua $\mathrm{K}$, amatuzva L, maratuwa Soegiarto.

94 rin maratuzva om. $\mathrm{K}$.

95 punapa G.

96 karaṇa nin wande $\mathrm{G}$, karanin karazoandc $\mathrm{K}$.

97 manke $\mathrm{G}$.

98 mawit $\mathrm{K}$.

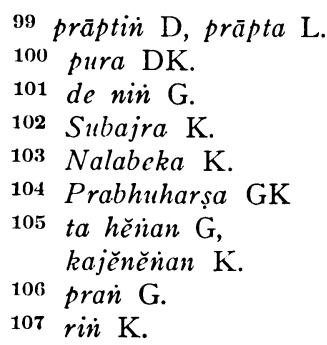

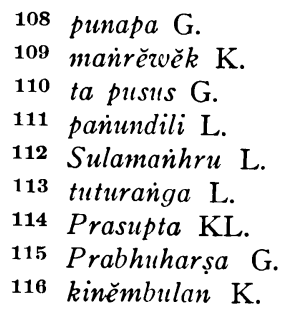


Now they are in the palace. And the marriage portion is withheld from us. Quickly king Koṣa waited upon his father-in-law, he saluted his father-in-law and asked: "What is the reason that our contract is made void?" The king of Mālawa answered: "My dear king, we do not know what caused the king of Kāsis to come here. Now he is in the bridal room." Koṣa asked: "Who gave him entrance?" The lord of Mālawa answered: "I do not know by what way he entered." Immediately the king of Magadha took leave. He went outside the palace and was met by the king of Srawanga, the lord of Kalinga and seventeen allies called king Cārudeṣna, Bajrānala, Nīlabāhu, Wikarṇa, Sulamaniru, śūlabajra, Wīroddhata, Sinhawadana, Braja, Wiroșa, Sutỉsṣna, Pragupta, Prawasta, Naladeka, Supadira, Praduharsa and Nisati. All were disposed to fight, together with their troops. Everyone was eagerly engaged and soon it was agreed upon to lay waste the city of Mallawa. The city was encircled, the ranks were closed densely, the drums roared loudly, like thunder. The king of Mālawa felt uneasy. He took counsel with the ministers and it was his wish to call in Daśabāhu. The minds of the courtiers were comforted, quickly they went to Daśabāhu and the king said: "My dear king, what is your plan? King Koṣa wants to conquer the city together with all forces of his allies. They have encircled the city, and their aim is your death." Dhătr's son answered: "My lord, Your Majesty need not be alarmed. Do not let the men of Mālawa march out with me, let them guard the city." Quickly Dhätr's son, standing in his chariot, sallied forth together with his troops; the prime minister Jayawirota, together with his men and elephants, attacked violently, like a clashing cymbal, like a surge lashed by the wind. Dead bodies made piles like mountains. King Koṣa, Siwanda and the lord of Kalinga went to meet Dhätr's son in combat; they were defeated and fell crashing down, together with their soldiers. Immediately the seventeen allies stepped into the breach; king Cāru$80 \mathrm{~b}$ deșna was killed. Bajrānala and Nilabāhu came forward; they were killed before they could strike. Wikarna and Sulamanru came forward; they died with horses and soldiers. Śūlabajra, Wīroddhata, Sinhawadana, Braja, Wiroṣa and Sutīkṣna came forward; all were killed by Dhātṛ's son. Pragupta, Prawasta and Naladeka came forward; the prime minister came to meet them and they died before they could strike. Supadira, Praduharșa and Nisati came forward; together they attacked the prime minister as if he were a young swine, his arrows were broken by Praduharșa and he was pressed hard by Supadira 
Supadira, san Nisati, paḍa mawa danḍa, pinupuh 117 de san Jayawirota, pějah ginambañ katiga de sañ mapatih. Śeșanya malayu tinut těken kuṭanya. Tuwin 118 maraja Koṣa, Srawangga, Kalingarāja pạ̣a malajěn atingal kuṭa, manunisi rin Ratnakaṇ̣a, sumawita rin maraja Puruṣāda. Mundur maraja Daśabāhu, anawan wadwa san Koṣa, Siwanda, Suśrawa len wadwa nin̉ ratu pipinanan. Sarat wadwa san̉ Kāśīpati, antukantuk ira ratna, kanaka, wastrādi len artha 119 nara jalu istri, sinrahakěn rin 120 sañ nāthen Mālawa, tan pahyun. Mañkwa san Daśabāhu anuli amwit rin sañ nāthen Mālawa. Mantuk sagraha 121 lawan 122 sañ rājaputrī; tuṣta sañ Mālawapati. Tan makaḍat prāpten pura Kāśīpati. Antyanta wwaǹ anininali,123 paḍa kamānuṣan, kasrěpan kabeh. Tuṣta san் Candrasinha mwañ dewī Rewatī, kalintañ ${ }^{124}$ garjita nira de nira amantu tan paśaraṇa, utawi de nin anak anwam prawira, hatur 125 tawan jarahan wastra, kalpa, ${ }^{125^{\mathrm{a}}}$ ratna, artha wwan akațah.

Alamilami hana anak in paṇịta naran bhagawān Wisradika, naran dewī Wisastri; pinaran, pinalampah de san Dhātṛutra, sinuñ ; tuṣta sañ prabhu marabi kalih. Alami añrěnö hana butrawa asuta istri hajĕñ, naran sań Sudasmini; naran in yayah ḍan hyan Musina;126 ya ta pinaran de san̉ Dhātrātmaja, anak jinaluk, asuñ sañ wipra, inalap de sań prabhu mapapasihan, tigan dina bhinakta, mantuk maren pura; tușta sañ priyā kalih. Mañka gěněp titiga gara sañ Daśabāhu. Alawas

81a makurĕn, paḍa maputra katiga, sawiji sowañ, sami kakuñ: de/wì Priyawatī 127 sutanya ṅaran sań Śāla, kadi sañ Daśabāhu rūpanya; sañ Wisastri masuta mětu sañ Dakṣa; sañ Sudasmini maputra mětu san Sucitra.

Tucapa maraja Puruṣāda. Tuștāmběk ira abala ratu titiga. Añrusuki 128 deśa rin Kāśīpati, rin Hastina. Kepwan sañ prabhu mwan para pañcaka, mayogasamādhi 129 manasihasih in Hyañ. Mañka sañ hyan Sadabija mañjanma rỉ dewī Prajādharì, magarbhinī. Mañka mijil; pitun dina hudan mas pisis; warṇa kadi candra pürṇama. Mankwa sakweh in karogasraya ${ }^{130}$ paḍa ruwat; tapas dadi ahirěn ; 131 wujil dadi magèn; cabol, rěyuk 132 dadi apajĕg; wunkkuk, paṇḍen 133

\footnotetext{
117 kapupuh G.

118 Towin $\mathrm{K}$.

119 artha om. K.

120 in $\mathrm{K}$.

121 sagrha $\mathrm{K}$.

122 lan L.

123 antyan kai wain
}

\begin{tabular}{|c|c|c|c|}
\hline & aninali $\mathrm{K}$. & 129 & may'oga masamadi $K$. \\
\hline 124 & kalih L. & 130 & sakweh ikain \\
\hline & wus jaya G. & & rogasraya $\mathrm{K}$. \\
\hline $125^{a}$ & kalya D. & 131 & tas dadi irěn $\mathrm{L}$. \\
\hline 126 & Susina G. & 132 & riyuk G, puyıuk L. \\
\hline $\begin{array}{l}127 \\
128\end{array}$ & Priyapuspawati K. & 133 & pande G. \\
\hline
\end{tabular}


and Nisati, both carrying clubs, but Jayawirota struck them with his mace and they died all three as their skulls were broken 11 by the prime minister. The others fled and were pursued even into their cities. King Koșa, Srawanga, and the king of Kalinga also fled, abandoning their cities, they took refuge in Ratnakaṇ̣a 12 and became Puruṣāda's vassals. King Daśabāhu retreated, carrying with him the soldiers of Koṣa, Siwanda and Suśrawa and the soldiers of the allied kings as prisoners. The soldiers of Kāsis's lord were heavily loaded, jewels, gold, clothes and the like, and male and female slaves were their loot; it was offered to the king of Mālawa, who did not accept it. Now Daśabāhu soon took leave of the king of Mālawa; he went home, with the princess he had married to the contentment of the lord of Mālawa. Without delay he arrived in the city of Kāsisi. Extremely numerous were the lookers-on and all were astonished and charmed. Candrasinha and queen Rewati were happy and they rejoiced exceedingly that they had got a daughter-in-law without having to ask a favour from anybody, and that their young son had proved a hero, who offered them a booty consisting of great quantities of clothes, gold(?), jewels and slaves.

Some time afterwards there was a daughter of the learned priest, the reverend Wisradika, called lady Wisastri. Dhātr's son went to her, asked for her and she was given him; the king was happy to have two wives. Some time afterwards he heard that there was a brahman who had a beautiful daughter called Sudasmini. The name of her father was the reverend Musina; Dhātr's son went to him, asked for his daughter and the brahman gave her. The king took her to wife and was entertained as a guest for three days. Then he returned to his city; the two wives were contented. Now Daśabāhu had got his three wives. When he had been married for some time, each of the

81a three wives had a child, all boys: the son of queen Priyawati was named śāla - like Daśabāhu was his stature; Wisastri gave birth to Dakșa; Sudasmini gave birth to Sucitra. ${ }^{13}$

Let us now tell of king Puruṣāda. He was happy to have the three kings as vassals. He laid waste the countries of Kāśī and Hastina. The kings and the religious men were distressed; they practised yoga and samädhi, praying to God. Now the lord Sadabija 14 descended into the womb of queen Prajādhari, who became pregnant. In due time He was born; for seven days it rained golden coins; His complexion was like the full moon. And all diseases and defects were healed: those who had a light-spotted skin turned dark; the dwarfs became big; those who were short and broad and ... acquired an ordinary stature; 
kāya palikan் 134 dadi aběněr; copet, pesos, 135 guwěn் 136 dadi samasta; date kera, wuta, wilalan, picĕk, kedĕr, 137 peleren 138 dadi awas mulat; bule, lampan, blan dadi pūrṇacarma; tuli děnkěk dadi an̉runu; lumuk dadi bisa anucap; wuḍug, ayan, buyan paḍa pürṇa. Wijil $138^{\mathrm{a}}$ in putra sañ prabhu pitu 139 candra tan pĕgat wwan asun dadah; 140 gěněp těmu bañu in̉aran sañ Sutasoma. Agěn, rumājaputra, tan pahyun akrama winidhi, kinen arabi, tan pahyun. Aguru rin sañ Wagiswaragnyanasrawa, tungal sapaguron lawan san yayah. Mingat in wěni maren prawata, kinĕmit in bala lanañ wadon san prabhu. Kapati lanan் wadon; ḍatan purohita nira: "Kaki prabhu, aja katunkul, duk, těka, ěndi sañkane? Lunha, ěndi parane? Těkane, aja sukha ; lun̉hane, aja duhkha." Enèt san̉ prabhu, něhĕr 141 mārdawa wuwus sañ dwiman.

Tucapa lampah sań Sutasoma. Amangih deśa, tan mandĕg. ${ }^{142}$ Liwat in pěkĕn, lumastari. Amārga rin panaṅswan; anuli rin kubwankubwan; liwat in panabĕtan; 143 kidulnya 144 sěma śawanyākweh. Araryan rin 145 ḍañka nira Bhațārī ; binañcana de sañ Gorī, tan kěna. Lumaris

$81 \mathrm{~b}$ mawu/kiran, kacuṇ̣uk bhagawān Keśawa, sinuguhan phala cacah, dimpa, uwi. Aniněp sakulĕm,146 eñjin lumaris maren bukit Pañcawatī, marĕk in bhagawān Sumitra, dinulur de san̉ rṣi Keśawa, sinayutan, tan kĕna de san kaki. Tumuli 147 bhațārì Prthiwī mapitutur, tan pantuk. 148 Śīghrāmwit i san Sumitra, lumaris maren Girirāja, dinulur de sañ Keśawa. Prāpteñ tīrthāmṛta, asūryasewana. Tinanguhan de sañ rși, tan sinaniśaya. Bawis mĕntas, lumaris, kacuṇ̣uk tan kĕpuh agěn. Sumawa san rṣi, tan sinańśaya. Kapangih sañ Gajawaktra amāṅsa janma. Ya ta pinituturan de sañ Jinamūrti, tan pahiḍĕp. Binĕḍag 149 sañ nṛ̣ātmaja. Mijil apuy saken kumbhanya, nāsikā lwir nāgarāja;

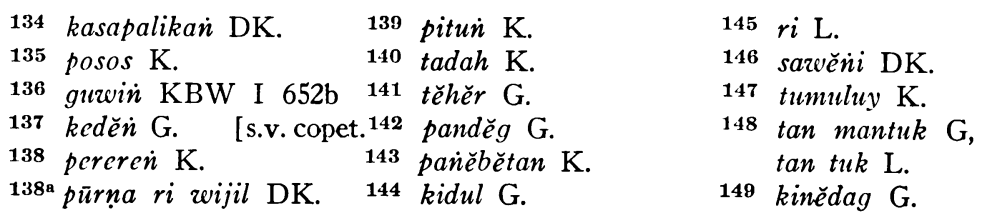


the hunch-backs, those who had the appearance of an eunuch, and... became hale; those whose lips were too short or too long, or had a hare-lip, got sound lips; those who were blind of one or both eyes, were afflicted with a winking of the eyes, had only one eye, had a cast in the eye or... now could see well; the albinos and those who had white spots on hands and feet or scald-head got a healthy skin; those who were dull of hearing or deaf now could hear well; the dumb could speak; the lepers, the epileptics and the idiots all became hale.15 After the king's son was born, servants for seven months at a stretch softly rubbed his limbs and, when his birthday came round, ${ }^{16}$ he was named Sutasoma. When he had grown to be a young man he did not wish to wed; even when he was told to marry, he would not do so. He became a pupil of Wagiswaragnyanasrawa, thus having the same teacher as his father. In the night he silently went away to the mountains, though he was watched over by the king's male and female body-guards. Men and women fainted with grief ; the king's chaplain came and said: "My dear king, do not be downcast. For things come, and from where do they come? Things go, and whither do they go? When they come, do not rejoice; when they go, do not grieve." The king recovered himself and then the priest spoke kind words to him.

Let us now tell about Sutasoma as he went his way. He reached the countryside, but did not stop. He passed a market-place, but continued. $\mathrm{He}$ came past a bathing-place and, after that, to plantations; he went past a hamlet; to the south there was a cremation-place with many dead bodies. He stayed in a temple of Bhatāin and was put to the test

81 by Gori, who found no flaw in him. He went on towards the mountains and met with the reverend Keśawa who offered him chopped fruit, dimpa and uwi.17 There he stayed for one night and the next morning went on to mount Pañcawatī, where he, together with the seer Keśawa,18 paid a visit to the reverend Sumitra. His great-uncle 19 tried to make him desist from his plans, but did not succeed. Immediately after that the goddess Prthiwi admonished him, but without result. Soon he took leave of Sumitra and went on to the King of mountains, accompanied by Keśawa. He came to a holy well and there he worshipped the sun. $1^{9^{\mathrm{a}}}$ The seer warned 20 him, but he did not heed his words. Immediately he came out of the water and continued his way. He came to the great wild kapok-tree; ${ }^{21}$ the seer was afraid, but Sutasoma paid no heed. He met with Gajawaktra, ${ }^{22}$ who ate men. The Jina incarnate admonished him, but he did not mind his words. He bore down upon the prince. Fire came forth from his frontal globes, his trunk was like the king 
manawil bunkah in wiyat, gambhīrānuluwun; katon natar i san nāgendra. Binalanakĕn rin 150 sañ Sutasoma, rĕmuk tañ prawata ri harěp sañ nṛpaputra. Śīghra pinanah rin śara bhidura, těrus pyah san Gajawaktra; tiba manohan 151 sañ Nekapawaktra. Lunha san் Ganamūrti, dinulurakĕn de san watĕk dewatā. Kari sañ Wāraṇawaktra, aminta jīwāsañgup anut sawuwus nira. Ya ta dinahut śara saken Dipakwadana. Mañkwātutur sañ Wāranawaktra, maněmbah ri 152 sañ ṇ̣pātmaja. Sampun pinituturan, mārdawa sañ Dipakwadana.

Śīghra lumaris lampah 153 san Sutasoma lawan san ṛ̣i, tumut san Wāraṇawaktra. Kañcit hana bhujaga rin giha, naran sañ Pāśarāja, sahasa harěp anahuta 154 ri sañ nṛpaputra. Wruh san Samberawaktra, sawegāmalan̉ ri harěp sañ ṇ̣pātmaja. Mañkwa mapluk sañ uragapati lawan san̉ Wāranakuñca. Pinulěd san Sāmajawaktra, kadi giri Mandaropamārubuh, mětu prabhāwanyāgni saken̉ kumbha $n$ umurub. Kaprabhāwan sañ uraganātha, ahyun paratra. Śīghra inuhuh de sañ nẹpātmaja: "Ih, ayo!" Sinirĕp jwala nin dipak. Ya ta matutur sañ Pāśarāja, ahyun anĕmbah ri 155 san Dwiradamukha, tinulak de san sāmaja, lin ira: "Dudu kami kañ anhhuripi sira. Ika si sěmbahĕn,156 guru nin hulun,

82a kṣatri/yānom, kan̉ ḍinerek in wiku." Mañka bhakti rin ${ }^{157}$ san̉ Jinakula, pinituturan, mārdawa manahnya.

Śïghra lumaris lampah san nṛpasuta. Amangih parwata apiṇ̣a danuja, atutuk guhālwa, amata śilāputih, kady abhūṣaṇa limut ampakampak,158 aswara guruh pracaṇ̣a. Arěs sañ pañcaka andulu, tan sinaniśaya 159 de sañ nṛpaputra. Ya ta hana wyāghra tan polih 160 mānsa, alapa, ahyun amanian in wěkanya, něhĕr diněmak wěkanya, $160^{\mathrm{a}}$ mananis akẹdalkĕḍal. Ya ta pinaran de san Sutasoma. Něhĕr paḍātanguh sañ wiku anirin, tan riněnö de sań nụpātmaja, lin ira: "E, sañ moń, aja dera pañan anak ira iku amĕlasakĕn. Uwakěna! Iñsun pañaněn! Sunu nira didine ahurip insun 161 matya." Ya ta inuwakakĕn leponya, malayu maren deśa śūnya. Mañkwa sañ wyāghra arangeyan; lin sañ Sutasoma: "Sañ suwanit, aja sańśaya, pananěn kami." Ya ta rinañsan sañ nب̣paputra ḍaḍanya, mumbul rahnya, siněsěp 162 rudhiranya. Tĕlas pějah san Jinakula, měnĕñ san் suwanit, tan kawasa amañana de nin sampun

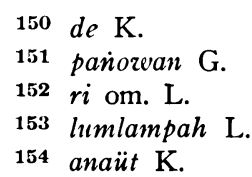

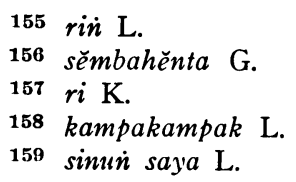

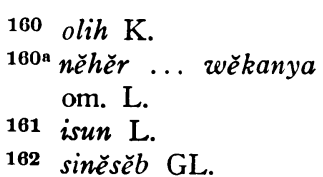


of snakes; he shook the foundations of the atmosphere, there was a loud noise and the courtyard of the king of snakes became visible. Mountains were thrown at Sutasoma, but they were annihilated before the prince. Quickly Sutasoma let off a thunderbolt-arrow 23 at Gajawaktra; it pierced his side. Nekapawaktra fell moaning to earth. Gana withdrew [and went back to heaven], accompanied by the gods. Wāranawakta remained, ${ }^{24}$ he begged Sutasoma to spare his life and promised to obey every word of his. So the arrow was taken out of Dipakwadana. Now Wāranawaktra's mind was cleared and he bowed before the prince. Soon he was instructed and Dipakwadana became a gentle person.

Sutasoma quickly continued his journey together with the seer; Wàranawaktra followed them. At a certain point on their way there was a snake living in a cavern, whose name was Pāśarāja; ${ }^{25}$ he suddenly tried to bite the prince. Samberawaktra was aware of it and quickly put himself in the way before the prince. Now the lord of snakes wrestled with Wāranakuñca. He wound himself about Sāmajawaktra, who crashed down like mount Mandara, but a mighty fire issued flaming from his frontal globes. The king of snakes was overpowered and near to death. Quickly the prince shouted to Gajawaktra: "Hey, stop!" and the blaze of the elephant was extinguished. So Pāśarāja's insight was cleared; he wanted to bow before Dwiradamukha, but the elephant held him back, saying: "It is not I who saved your life. That is the man who should be bowed to, my master, the young

82a kṣatriya, who is accompanied by bhikșus." Now the snake paid homage to Jina's son, he was instructed and his heart became gentle.

Quickly the prince continued his journey. He reached a mountain that resembled a danuja. For mouth it had a large cave, for eyes white rocks, as it were for ornaments clouds and mist, for voice a violent roar. The religious men were afraid as they saw it, but the prince did not heed. Now there was a tigress $25^{\mathrm{a}}$ who could not find meat and, as she was hungry, wanted to eat her cubs. Immediately she seized her cubs, who cried and squirmed. So Sutasoma went to her. Immediately all the bhikșus who were with him tried to withhold him, but he did not listen to them and said: "Hey, tigress, do not eat your pitiful cubs! Let them loose and eat me! Let me die, that your children may live." Then she let her cubs loose and they fled into the jungle. Now the tigress reached for Sutasoma and Sutasoma said: "Tigress, do not be afraid! Eat me!" So she clutched the prince in the breast; the blood flowed forth and she drank it. Soon Jina's son died and the tigress stopped drinking; she could not eat him, because she already was 
sěwĕh de nin swanita. Mañka paḍa 163 mananiis para wiman; mwan் sañ dipak, san̉ nahipada,164 padākusah ananisi pāda sañ Sutasoma. Lin sañ suwanit: "E, sañ Sāmajawaktra, sañ nāgapati, jana, paran dera tanisi iku ?" Lin san wiku: "E, san mon, kusuma dibya iku. Dene san̉ Wāraṇawaktra, Nāgapāśa, sañkane iku ananiis 165 dene iku 166 aguru." Mańkwa ananiis 167 sañ wyāghra makusah,168 aminta pinějahan de sań dipak, uraga mwań sañ ṛ̣i, lin ira: "Pakanira pějahana manira." Mojar sañ Sāmajawaktra, sañ uraga: "E, sań mon, sugyan ta guru nisun 169 iku." Mañkwa amalampah pinějahan san wyāghra. Lin sań sāmaja $169^{\mathrm{a}}$ uraga : "Orana wĕkase guru nin hulun mañkana." Maṅkwa

82b anibani/ba 170 ananis amalaku ${ }^{171}$ pinaten: "Raden, yan ${ }^{172}$ pakanira ahuripa, manira aguru in pakanira." Mañka ${ }^{173}$ sañ hyań Śakra mawikalpa: "E, sañ moñ, těměn sira ahiḍĕp in ujare 174 san Sutasoma ?" Tuměna san் wyāghra, sumahur: "Singih". Mañkwa mahurip sañ Sutasoma. Tușta sañ ṛ̣i mwañ san̉ bhujaga, dwirada 175 padānañãjali, mwañ sañ wyāghra śobhānastuti, mārdawa manahnya. Paḍanàstuti gati nira, paḍa pinituturan, pậla manut sawuwus i sañ Jinamūrti. Tușta san rṣi de nira satya gati nira katiga. Artha jana katiga, sami bhinagawān nāma 176 de sañ Jinakula: sañ Gajawaktra liningan san Pañcakadipak, sañ nāga liningan sañ Uragadwiman, sañ wyāghra liningan san Puhunbhikșuka. Sampun winuruk in tapabrata, kinantunakĕn in giri Kopa.177

Sañ Sutasoma lastari maren Mahāmeru, mwañ sañ Keśawānirinn. Śīghra prāpten Rajaprawata; sañ Keśawa mamwit, mantuk marè Wanawatī mawarah rin bhagawān Sumitra. Tuṣta manah ira de nira anwam, ambĕk ahinsaka, matapa rin Rajaprawata.

Tucapa rṣisanggya mapupul, arĕs de san Sudasasuta; awrin para watěk dewatā. Mañkwa ginunita san̉ Sutasoma de sañ hyan Indra: "Sañ Sutasoma juga amějahana." Mankkwa ta tibanana 178 bañcana de sań Śakra, widadari, tan kawěnan, larut kan̉ bañcana. Tigan dina, tigan̉ kilĕm,179 tan kĕna. Mañkwa san̉ hyan் Indra marūpa widadari, naran sañ Kendriya, mara amañcana, tan polih. Keranaan asěmu kawu-

163 pada om. DK.
$\mathbf{1 6 4}$ para wiman, san dipak
mwain sañ nahipada $\mathrm{K}$.
$\mathbf{1 6 5}$ ihananis L.
$\mathbf{1 6 6}$ siku L.
$\mathbf{1 6 7}$ mananis DK.
$\mathbf{1 6 8}$ akusah $\mathrm{K}$.
$\mathbf{1 6 9}$ ninsun $\mathrm{K}$.
$\mathbf{1 6 9 a}$ Samajazeraktra DK.
$\mathbf{1 7 0}$ aniba G.
$\mathbf{1 7 1}$ malaku K.

172 y'en $\mathrm{K}$.

173 Mankw'a K.

174 ujaren $\mathrm{L}$.

175 Dwiradasy'a DK.

176 bhinazvanama L.

177 ginakopa $\mathrm{D}$, likopa $\mathrm{G}$, gihopa L, Ginakoșa (? name of a place) KBW IV 634a, s.v. ginakoșa. Cf. CP 227 Kan jyeștha wyāghra pine, arthajanma, wruh in lara de nin tan panut yayah rena lumakw atapa iaran bhagazeān Suzanit, matapen giri Kopa, and 73a naran Wagiswaragnyana, matapei giri Kopa.

178 tinibanana $\mathrm{K}$. 179 tilěm G, kulěm DK. 
satiated with the blood. Now all the religious men wept, and the elephant and the snake both wept loudly over the feet of Sutasoma. The tigress asked: "Well, Sāmajawaktra, snake and you, men, why do you weep over him ?" The bhikșu answered: "Ah, tigress, this was a flower from heaven. As for Wāranawaktra and Nāgapāśa, they weep because they were his pupils." Now the tigress wept loudly and asked the elephant, the snake and the seer to kill her; she said: "You must kill me." Sāmajawaktra and the snake replied: "Ah, tigress, we rather would that our master [were still alive]." Again the tigress craved to be killed. But the elephant and the snake said: "Thus was not the

$82 \mathrm{~b}$ instruction of our master." Yet she repeatedly threw herself to earth, wept and asked to be killed: "Prince, if you will come to life again, I shall be your pupil." Now god śakra asked: "Well, tigress, will you really mind the words of Sutasoma?" The tigress looked up and answered: "Indeed." Then Sutasoma was restored to life. The seer and the snake and the elephant were happy and bowed and the tigress rejoiced and praised Sutasoma; her mind had become gentle. All praised his deed, all were instructed and all took to heart every word of the Jina incarnate. The seer was glad that the three remained true to their words. All three learned to understand the tongue of men and all of them were ordained as religious men and given holy names by Jina's son: Gajawaktra was given the religious name of Pañcakadipak, the snake was given the religious name of Uragadwiman, the tigress was given the religious name of Puhunbhikșuka. Soon they were accomplished in the observances of asceticism and were left behind on mount Kopa.

Sutasoma continued on his way to the Mahāmeru and Keśawa went with him. Soon they reached the King of mountains; Keśawa took leave and returned to Wanawati, where he informed Sumitra. Sumitra was glad to know that Sutasoma, as a young man, and with benevolent mind, was practising austerities on the King of mountains.

Let us now tell of the host of seers, which was assembled. They were afraid of Sudasa's son; all the gods were distressed. Now god Indra thought Sutasoma the right man: "Only Sutasoma will kill him." So Sakra and the widadaris had to lead him astray, but they could not prevail over him; the temptation failed. For three days and three nights they continued tempting him, but did not succeed. Then god Indra assumed the form of a widadari called Kendriya, who went to tempt Sutasoma, but without result. She felt ashamed, showed herself undressed and tried to wash the feet of the prince; at that moment 
dan, ahyun añrahup suku nira sañ nṛpasuta; mur sañ Sutasoma, marūpa Jina. Mañkwa bhakti sań hyań śakra mwañ dewatā, ṛ̣igaṇa, catur lokapāla, nawa dewatā, apsara, apsarī, mwañ sañ Rudra, paḍa bhakti. Mañkwa amicāren ambĕk sañ ṇ̣pātmaja: "Yayah reṇa nin hulun pan 180 mānuṣa ta, yen 181 wruha kañ densěmbah iki dewa, pradene nora wruh kan densěmbah." Ya ta mur sañ hyan Sadabija, wāhya san Sutasoma. Kagyat para walabhit, pada mur, meran kabeh. Kari 83a san Sutasoma mayo/gadhāraka.

Tucapa san ṛ̣i Sumitra; kinen sañ Keśawa lumawada ri san Sutasoma. Bawis mańkat sañ Keśawa, prāpten Mahāmeru; kapangih san nṛpātmaja; tușta sañ ṛ̣i. Śīghra mawarah sañ nụpātmaja yen dewatā paḍānambah $181^{a}$ rin sira: "Widyādharī paḍāmañcana,182 tan tumama. Tumuluy bhațārendra matěmahan apsarī naran Kendriya, amañcana, polahnya 183 asěmu kawudan, harěp arahup suku nin pun anak. Pun anak andoh. Meran், kari aněmbah. Mañkwa pun anak ahyun 184 mantuk mareñ nagara." Tușta manah ${ }^{184^{a}}$ sañ Keśawa. Mańkwa dinulur de sañ rṣi, tumurun saken Prawataraja, mahawan tawañ, meh prāpte 185 pura Kāśindra, tumurun mạ̣arat ri lambun in acala. Sĕk tan் 186 phala tasak, puṣpanyānēḍèn, walaharnyāhĕniñ, matsyanyākweh, kady anuñsun. Tușta manah sañ Jinakula, masūryasewana sirāraryan san ṛ̣i madiwasraya.

Tucapa sañ Daśabāhu pinurug in weri, wadwa san Puruṣāda mapran lawan bala sañ Daśabāhu, madumduman para putra katiga. Sor tan danuja de nin para putra. San̉ Daśabāhu mapran̉ lawan san Jayawiṣnu. Maprań tigañ dina ramyārok; katĕlasan hru, cakra rěmĕk, gadā tikĕl, silih prañ, khaḍganya pěpĕr rin tañan, maprěp, wěkasan silih gĕlut, kaprĕp mukhanya, tan panapa, kěnen nakha bațuk in danuja, rahnya 187 muñcar, malayu, tinut de sañ bhūpati, manusup in kānana, tinut de san nātha. Mañka kacuṇụuk san Sutasoma de nin danuja. Tĕka, marěk aněmbah rin san் nṛpātmaja. Lin sañ Sutasoma: "Asura, paran kita iki ?" Lin san Jayawiṣnu: "Pukulun, manira danuja, kanḍap 188 apran, 189 anẹda inurip de nin andika pakanira. Naran in patik bra

\footnotetext{
180 pan om. $\mathrm{K}$.

181 y'an DK.

181a maněmbah $\mathrm{K}$, 'aněmbah L.

182 padambañcana $\mathrm{G}$.

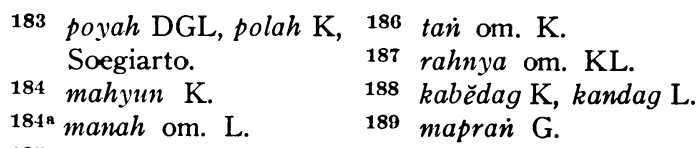


Sutasoma disappeared and showed himself as Jina. ${ }^{26}$ God Śakra paid reverence and the gods, the host of seers, the four guardians of the world, the nine gods, 27 the apsaras, the apsaris and Rudra, all paid reverence. Now the prince considered in his heart: "My father and mother are but men. If they would have known who is the person they now adore, [they would have behaved differently], but they did not know who is the person they now adore." So the lord Sadabija disappeared and Sutasoma manifested himself. The gods were awed, they all disappeared, everyone of them was ashamed. Sutasoma remained 83a alone, in steadfast concentration.

Let us now tell of the seer Sumitra. He ordered Keśawa to go to see Sutasoma. Immediately Keśawa left; he reached the Mahāmeru and, to his pleasure, found the prince. Soon the prince told him that all the gods had bowed to him: "All widyādharis tempted your son, but could get no hold over your son. Thereupon god Indra assumed the appearance of an apsari called Kendriya, who tempted your son. She showed herself undressed and tried to wash the feet of your son. But your son withdrew. The god was ashamed and bowed. Now your son wishes to return to the city." Keśawa was pleased and Sutasoma, accompanied by the seer, descended from the King of mountains and travelled through the air. They had nearly reached the city of Kàsí, when they descended to the slopes of a mountain. There was abundance of ripe fruits, the flowers were in full bloom, the ponds clear and the fishes numerous as if they came to a durbar. Jina's son was pleased, he worshipped the sun and the seer stopped to pay reverence to the gods.

Let us now tell of Daśabāhu. He was harrassed by his enemies, the men of Purușāda. These waged war against Daśabāhu's troops, the command over whom was equally divided among his three sons. The danujas were defeated by the princes. Daśabāhu fought with Jayawiṣnu. They fought for three days, with great noise and face to face; their arrows were spent, their discuses smashed, their clubs broken; they came to close quarters, their swords burst in their hands, they fought with fists and in the end they wrestled, they beat each other in the face, but to no effect; Daśabāhu with his nails hit the danuja in his belly, so that the blood flowed forth; the danuja fled, pursued by the king; he tried to hide himself in the wood, but still the king pursued him. Now the danuja met Sutasoma and, lo, he went to the prince and bowed before him. Sutasoma asked: "Asura, what about you?" Jayawiṣnu answered: "My lord, I am a danuja, who has been defeated in combat. I beg Your Grace to save my life. The name of your servant 
pun Jayawișnu." Lin̉ san̉ Sutasoma : "Sapa werinta ?" "Pukulun, maraja Daśabāhu." Tușṭa san Sutasoma : "Aja kita sañśaya." Śīghra ḍatañ 190 sañ Daśabāhu, jěněr aninali 191 wwań apěkik, hemane awadwa dānawa: "E, sapa aranta?" Lin sañ nẹpātmaja: "Nhulun 192 dudu tuhan in dānawa, tan kula nin danuja. Naran $192^{\mathrm{a}}$ in hulun Sutasoma, tumurun

83b saken 193 patīrthan. / De nin rākșasa iku amalaku inurip sañkane sun kukuhi." Lin sañ Dhātrātmaja: "Siñ malaña dadi weri nin hulun." Mañkwa malaga sañ Daśabāhu lawan san Sutasoma. Sañ Daśabāhu mamanah rin sañ ṇ̣pātmaja, bāṇanya, tĕka, hilan̉ ri harĕp i san ṇ̣pātmaja. Wruh bhagawān Keśawa; ya ta sinapih de sañ Keśawa: "Bapa, sampun! Sanak ira iku, sañ lumakw atapen prawata, naran Sutasoma." Mañkwa binuñcal panah ira de san Daśabāhu; rinañkul sañ antěn ira de Dhātrātmaja: "Uḍuh, ari nin hulun!" Yayi, wentěn ari ni 194 pun kaka, kanyā, naran Puṣpawatī; pinakapatnya nira!" Lin san Sutasoma: "Sakarsa kakāji!" Mañka pinrih danuja ahyun pinějahan,195 tan pasun san antěn: "Yen pinakṣa, sahandika! An̉hin pun yayi masa ahyuna yen añalap rayi Pāduka Bhatāra!" Man̉kwa mārdawa manah sañ kaka: "Lah, sakarsa nira yayi!" Mañke ta kinen mantuka rākṣasa ika, tan pahyun, anẹḍa warāmṛta, ahyun atapa, aminta winarahan ujar kaśāntikan.196 Tușta manah sañ kaka mwañ 197 san rși. Sampun winarahan de sañ Jinakula, liningan san Asuraparaśujaya. Mantuk sañ Daśabāhu lawan san̉ antěn; sañ ṛ̣i Keśawa mantuk hawan 198 tawañ. Saǹ bhūpati makarwan 199 ratha lawan sañ antěn, dinulur in wadwa. Sañ Asurawijña kari matapen Kuraṇ̣̂ācala.

Lampah sañ Dhātrātmaja liwat in Magadharāja, anuli rin Srawangapati, rin Kalingarāja,200 wințttakĕn 201 yen kawon de nira. Araryan sañ nātha irika; sira patih kinen mantuka karuhun, maturen 202 para patn̄i, kinen kapangiheñ 203 udyāna Ratna lawan dewī Puṣpawatī lawan para putra, sań śāla, Dakṣa, Sucitra, sami kinen kapangihen taman. Sañ nāthāniněp in Awanga. Śīghra prāpten Kāśīpati, marĕk tañ 203* dūta ri sañ dewì mwañ sañ putra katiga, matur yen sañ Sutasoma tumurun saken wukir: "Pāduka Swari kapangihen udyāna, saha gṛha,

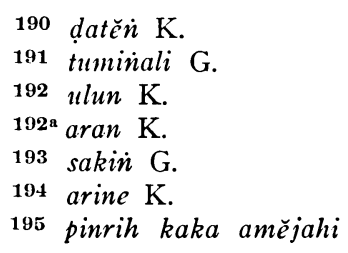

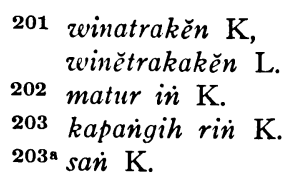


is Jayawiṣnu." Sutasoma asked: "Who is your enemy?" "King Daśabāhu, my lord." Sutasoma was satisfied: "Do not be afraid." Soon afterwards came Daśabāhu. He was astonished to see a handsome man and regretted that he had a dānawa for subject: "Hey, what is your name?" The prince replied: "I am not a lord of the dānawas, nor am I a relative of the danujas. My name is Sutasoma; I have just come

83b down from a holy place. As that rākṣasa asked me to save his life, I stand by him." Dhātr's son said: "Whoever thwarts me becomes my enemy." Now Daśabāhu attacked Sutasoma. Daśabāhu loosed off arrows at the prince, but, lo, they disappeared before the prince. The reverend Keśawa saw this and he withheld Daśabāhu: "My friend, stop! That man is a relative of yours, who went to perform austerities in the mountains; his name is Sutasoma." Now Daśabāhu threw his arrows aside and Dhātr’’s son embraced his younger cousin: "Ah, my cousin! My dear, your cousin has a younger sister, a virgin, called Puspawatī; take her to wife!" Sutasoma answered: "As my cousin the king wishes!" Now Daśabāhu made for the danuja, wishing to kill him, but his cousin did not allow it: "If you will do it by all means, so let it happen according to your word. But then, how would your cousin wish to take Your Majesty's sister to wife!" So his cousin's heart was softened: "Well, be it as you wish!" The rākșasa was told to go home, but he would not, he begged for the excellent nectar; ${ }^{28}$ he wished to perform austerities and asked to be instructed concerning tranquillity. The prince's cousin and the seer were pleased. Soon Jayawiṣnu was instructed by Jina's son and was given the religious name of Asuraparaśujaya. Daśabāhu went home together with his cousin and the seer Keśawa returned flying through the air. The king and his cousin travelled in the same chariot and the troops escorted them. Asurawijña remained to perform austerities on mount Kuranda.

Daśabāhu's way led through Magadha, then through Srawanga and Kalinga, and he told Sutasoma how he had conquered these kingdoms. The king stopped there; the prime minister got orders to go home before. He had to inform the consorts, who were summoned to meet the king in the Jewel-park 29 together with princess Puspawati and their sons, saāla, Dakṣa and Sucitra; all these were summoned to wait upon the king in the park. The king passed the night in Awanga. The messenger soon reached Kāsí, went to the queens and the three princes and informed them that Sutasoma had come back from the mountains: "Your Majesties with the retinue may please to meet the king in the park and to take the princess with Them. Your 
raden dewī pakanira baktaha, raden katiga pakanira tumut." Tan makaḍat, saha purī madan. Dewī Puṣpawatī ananis rahina wĕnìi, kañĕn 84a in yayah rena nira, tan pahyu/n tumuten san் prabhu. Mañka inipuk in dewara 204 katiga, tan pahyun, anhin matya tumuten yayah rena karsa nira. Mañkwa ta hana iña nira, naran Jayasurāga; nĕhĕr mārdawa, dinus inahesan.205 $\mathrm{Ya}$ ta mankat hawan ratha, wadwa matungalan damar, polah in aměnakĕn 206 kulěm. Sawega prāpteñ udyāna Ratna; eñjin ḍatan sañ Daśabāhu lawan sañ antěn. Sampun samāpta hinarayana san் Jinakula, siněmbah in para putra, maniněp tigan் kilěm. 207 Ahyun asūryasewana sañ Jinamūrti ; hana wuhaya asisik kañcana, marĕk in 208 san nrpaputra, ya ta matěmahan danuja bhaktīn 209 sañ Sutasoma.

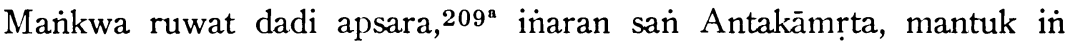
amarālaya. Mañka sañ Sutasoma ginunita ahyun kinare lawan sañ Puṣpawatī. Mañkwa kasamāptan de nin yodha mantri; eñjin anundan bhujañga rṣi śewa sogata. Sampun mantuk, kinare hanen dalěm pawaranan.

Gĕnĕp sapěkĕn akrab kalasa, mañkwa san் Sutasoma amwit mantukeñ Gajāhwaya; tuṣta manah san் Daśabāhu; putra nira katiga maniirin saha bala, amārga riñ pasisi. Mañkwāraryan ahutusan sañ nṛpaputra ${ }^{209^{b}}$ maturen san் nātha yen 210 ranak ira ḍatan. 211 Tuștāmbĕk sañ prabhu mwan் san் nareśwari, gipih adan; amapag wwan் sapurī. Śīghra mañkat san̉ bhūpati, sawega kapapag 212 san nareśwara tuṣta manahnya ; sawega prāpten Hastināpura. Mañkwa san் Sutasoma biniseka prabhu rin Hastina. Malawas makurĕn, maputra jalu sasiki, naran san் Ardhana. Mañrènö sań Daśabāhu, mañlawad maren Hastina, tuṣta san nātha mabesan kaponakan, aninĕp sapĕkĕn, tan pĕgat hinarayana de san் Jinakula, rinĕṅgarĕṅga san் kaka. Man̉kwa amwit san் Dhātrātmaja ri san் antěn mwañ riñ $212^{\mathrm{a}}$ sañ paman, $212^{\mathrm{b}}$ śíghra prāpten Kāśípura, balanya mandulur.

84b Tucapa maraja Puruṣāda, alawas ake/sah tan 213 pananti yodha, maren kānana; kapangih wadwa sañ Daśabāhu apisah,214 binuru de san் Naramānisa, meh kacaṇdak; ya ta kahajirin̉ śilā 215 angon in 216 pāda rěñcah. Tiba san் bhūtarāja, kasakitan, magěrin, karaněhan,217

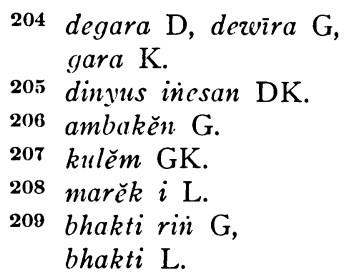

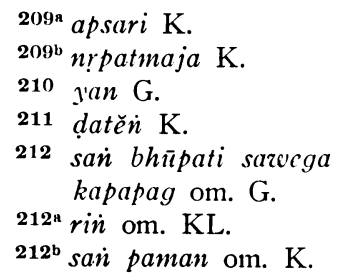

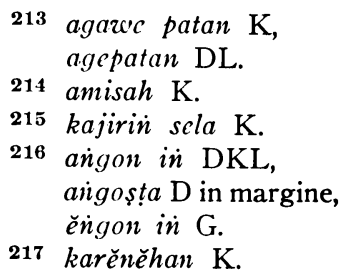


Majesties' three sons should also come." Without delay the queens, together with their retinue, dressed. Princess Pusppawati wept day and

84a night, she longed after her father and mother and would not obey the king. Her three sisters-in-law spoke gently to her, but she would not go, she rather wished to die and go after her father and mother. Now there was a foster-mother of the princess, called Jayasurāga, [she spoke to her and] soon the princess was reconciled and she was bathed and dressed. So they left by chariot; each of the soldiers carried a torch and thus they found their way through the night. They reached the Jewel-park quickly and next morning Daśabāhu arrived, together with his younger cousin. Soon a meal had been served to Jina's son and the princes paid homage to him. He stayed there three nights over. The Jina incarnate wanted to worship the sun; now there was a crocodile with a golden hide, ${ }^{30}$ she came to the prince, then took the form of a danuja and paid reverence to Sutasoma. She was freed and became an apsari, called Antakāmrtā, and returned to heaven. Now Sutasoma was consulted and he was willing to be wedded to Puspawati. The officers and ministers fully agreed and next morning he summoned the priests: seers, śiwaites and Buddhists. Soon he went to the city and was wedded in the bridal room.

When they had been married for full five days, Sutasoma took leave to return to Gajāhwaya. Daśabāhu agreed and his three sons escorted the prince together with troops; they took their way along the beach. Then they rested and the prince sent a messenger to inform the king that his son was coming. The king and the queen rejoiced, they dressed hurriedly and all the people in the court came to meet them. Quickly the king went out and hastily [Sutasoma] came to meet him; the king was completely happy; soon they reached Hastināpura. Now Sutasoma was consecrated king of Hastina. When he had been married for some time he had one son, who got the name of Ardhana. When Daśabāhu heard this, he came to Hastina to visit Sutasoma. The king was pleased to have a grand-nephew; he stayed for five days and all the time the elder cousin was entertained and offered all kinds of ornaments by Jina's son. Then Dhätr's son took leave from his cousin and his uncle and soon arrived in the city of Kāśī, escorted by his troops.

84b Let us now tell of king Purusaada. He was away from home for a long time and did not stay with his soldiers. He went into the jungle and there found a stray soldier of Daśabāhu. Naramānsa hunted him and had nearly seized him, when his foot was pierced $30^{\mathrm{a}}$ by a stone. The king of the bhütas fell and became ill; he pined away as the illness 
rapuh rasa nin prabhu. ${ }^{218}$ Mañkwa masasanii acaru ratu satus salö nin̉ wimāna. Mañrěnö sañ Kālaweśma; waras de nin kasaṇụun. Ḍatañ 219 tan̉ bhṛtya, paḍānulati ri 220 sañ nātha. Naran in wadwa sań Indrabajra, sañ Wimona, Dumdumbika, Sumala, Bajra, Kaluṣa, Dumendagra, Pakṣinndrawaktra, Dwiradamukha, Subhanga, Wikațākṣa, Golakșa, Dumala, Ketu, Durlakṣaṇa,. Wikampya, paḍānaniis i jön 221 sañ prabhu, matakwan mūla nin sakit. Lin sañ prabhu: "Kami amburu mānuṣālalaku; meh kasambuta denkwa; ya ta kasaṇụun pāda kami. Tiba kami sakit in kānana; nĕhĕr ṅhulun $221^{2}$ asasañi ababantěn 222 ratu satus salö nin wimāna. Mañka waras kami. Mañkwa kita paḍa ameta ratu."

Śīghra mañkat sakweh in bhūta sewaka tuwin maraja Puruṣāda munge in wimānāhělar mas, tumut tan bala śata koṭi paḍāsraṅsranan analap para nātha. Hana molih ratu, hana kěna sẹdeennya akrama, kasikěp těka nin pipinanaanipun. Hana ratu akalañĕn rin ratnākara, kabandha sa-udaranya. Hana nātha acañkrama rin acala, kasikěp saudaranya. Hana rāja abuburu, kabandha rin kānana. Hana nātha dinon in pran் amapag, kasikěp sa-udaranya. Hana nātha len kañ kěna 223 kacidren kulěm, kabandha sānujanya. Hana ratu ahyun amapagāprañ, kabhakșan kabeh. Len san nātha rin Mālawa amagut, kasikěp de san Naramāṅsa. Lawan san̉ nāthen Sinhhala pějah amukamukan kalawan arinya kasaña. Kirañ satungal satus, mañka san nātha rin Widarbha, naran maraja Bhoja, kinārya gĕgěnĕp satus. Śīghra sinrahakĕn in sañ Kālaweśma; lin sañ Kālaweśma: "Sapārane para nātha denta 224

85a haturakĕn iku? In ĕndi sañkane?" Sumahur san hyañ Rudra: "Puni/ka nātha rin Wallabha, naran san Nalabeka; sañ nātha rin Walasri, naran maraja Wirasanda, kań pipinanan parĕn 225 ratu pipitu, naranya maraja Śāla, Swalandi, śūrajana, Janati,226 Rukmaketu, Paśubrata, Subrata; kaḍaton in Walabita, kan anundañ nātha rin Prasala, naran maraja Wisradana; prabhu rin Lénka, naran maraja Wigrañsu,227 unda-

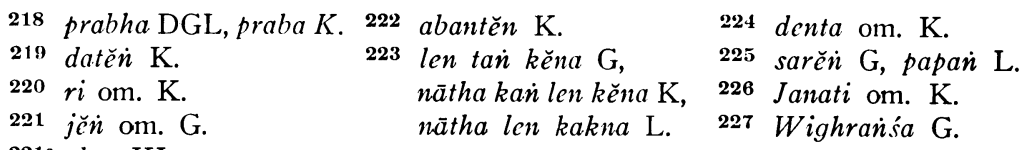
221a ulun KL. 
became worse and the king felt low-spirited. So he promised Kālaweśma 31 to sacrifice a hundred kings, each seated in a wimāna (?). ${ }^{32}$ Kălaweśma heard him and the wounded foot was healed. Now came his men, all looking for their king. The names of the soldiers were Indrabajra, Wimona, Dumdumbika, Sumala, Bajra, Kaluṣa, Dumendagra, Pakṣinndrawaktra, Dwiradamukha, Subhanga, Wikațākṣa, Golakṣa, Dumala, Ketu, Durlakșana and Wikampya. They all wept at the feet of their king and asked the cause of his illness. The king related: "I was hunting a man on foot and nearly had I seized him, when my foot was wounded. I fell and became ill in the jungle. Then I promised to sacrifice a hundred kings, each seated in a wimāna. And so I was healed. Now you all must march out to find kings."

Soon all the bhūta knights set out, and with them king Puruṣāda, seated in a wimāna with golden wings, a milliard soldiers followed them, all eager to capture kings. One king was that moment victorious over other kings, one was surprised even as he was going to line up his troops, and was seized together with his allies. One king was diverting himself on the beach of the ocean, he was taken captive together with his brothers. One king was making an excursion in the mountains, he was seized together with his brothers. One king was hunting, he was taken captive in the jungle. One king was attacked in open war and encountered the attack, but he was seized together with his brothers. Another king was treacherously surprised in the night and taken captive together with his sons. One king tried to march against the invaders. They all were made food [for Kālaweśma $3^{32}$ ]. And the king of Mālawa came to meet the attackers, but was seized by Naramanisa. And the king of Sinhala died in the attack together with his nine younger brothers. Now there was only one wanting to the hundred and the king of Widarbha, called king Bhoja, was made to complete the hundred. Soon the kings were offered to Kālaweśma. Kālaweśma asked: "What are the names of these kings you are offering $85 \mathrm{a}$ to me?" God Rudra ${ }^{24}$ answered: "These are the king of Wallabha, called Nalabeka; the king of Walasri, called king Wirasanda, and together with him seven allied kings, called king śāla, Swalandi, śūrajana, Janati, Rukmaketu, Paśubrata, Subrata; the king of Prasala, who resided in the court of Walabita - his name king Wisradana; the lord of Lẹnka, called king Wigrañsu; his twenty vassals, called 
nuundanan ira dwidaśa, ṅaran maraja Dharmarāja, maraja Wiṣnu,228 Namandara, Kalandaka, Pusandara, Ugrabāṇa, Managanda, Rukmasanda, Ruksmagana, Wiroṣa, Sanamanda, Sugradana, Waradāgra,229 Wiṣāna, Warada, Wisandara,230 Pratasura, Jātawara, Wijāta, Sujāta ; nātha rin Mandiratiga; 231 prabhu rin Antasara, naran maraja Candrapanānujanya 232 pituwělas ṅaran maraja Sudarga, Dunagra, Wigrana, Grana, Supada,233 Daragra, Namasanda,234 Pradasa, Mānadhana,235 Mornaba,236 Isaka, Susenda, Wṛsesa, Wṛsenda, Jayanda, Wijakesra, nātha rin Prasuba, Dewara ; ${ }^{237}$ nātha nawa gaṇanya, 238 naranya maraja Banaba, Banajaya, Sayastra, Durbhanga, Graganda,239 Wigrada,240 Sulaja, Wirasanka, Wradara,241 nātha rin Burikatana; 242 ratu rin Palawa,243 ṅaran marajāruṇa, sapta sanak, arinya naranya maraja Sutāgra, Dasapata, Wīrakātma, Prasuta, Bisaka, Jayabāhu; suta nira maraja Bajrada,244 ratu rin Wilatma, salikur 245 sanak, jyeștha 246 san̉ Baǹli,247 Sinhhātma, Sinnhawadana, Bahuwinda,248 Bāhyadanta,249 Nagradanta, Upasanda,250 Wiradagra,251 Manamoha, Katagna, Sanawira, Nilabraja,252 Sugindra,253 Wasnajana, Suprajana, Wisanda, Kulabra, Ketabraja; 254 nātha rin Gopāla, sawĕlas sanak, jyeșṭha 255 naran maraja Himacandra, Ganindra, Gameka, nāthen Tundaga, maraja Trana,256 Padmaketu, Maya, Sulandrasta, Sujaraja, Měta; ratu rin Mayūra, maraja Subadětta; nātha rin Mālawa, maraja Indupati ; 85b nātha rin Widarbha, maraja Bhoja. Gěně/p satus punika." Lin sañ san̉ Kālaweśma: "E, maraja Puruṣāda, norana karsa mami 257 ratu iku kabeh; ika 258 si inon் karsani hana ratu rin Hastina, naran maraja Sutasoma; yen kĕna iku, uwakěna 259 ratu satus iku!"

Man̉kwa mañkat maraja Naramāṅsa, lumurug maren் Hastina. Kañcit ta 260 datañ 261 bhagawān Winayana, halinhalin riñ 262 maraja Purușāda, aken ambaktaha 263 wadwa makweh : 264 "Kaḍaton iku akeh para

$\begin{array}{ll}\mathbf{2 2 8} & \text { Wisna DK. } \\ \mathbf{2 2 9} & \text { Waradatra } \mathrm{K} . \\ \mathbf{2 3 0} & \text { Wisanandara } \mathrm{K} . \\ \mathbf{2 3 1} & \text { Mandira titiga } \mathrm{K} . \\ \mathbf{2 3 2} & \text { Candrasana, } \\ & \text { nujanya } \mathrm{K} . \\ \mathbf{2 3 3} & \text { Supata } \mathrm{K} . \\ \mathbf{2 3 4} & \text { Namasanda om. KL. } \\ \mathbf{2 3 5} & \text { Manadaba } \mathrm{L} . \\ \mathbf{2 3 6} & \text { Monaba } \mathrm{L} . \\ \mathbf{2 3 7} & \text { san Dezwara } \mathrm{G} . \\ \mathbf{2 3 8} & \text { nätha nawaganya } \mathrm{G}, \\ & \text { kazwana watananya } \mathrm{K} . \\ \mathbf{2 3 9} & \text { Traganda } \mathrm{K} . \\ \mathbf{2 4 0} & \text { Witrada } \mathrm{K}, \\ & \text { Wigrana } \mathrm{L} .\end{array}$

241 Pradara K.

242 Buritakana G, Bhurikattana L.

243 Pawala DL.

244 Bajrata K.

245 sakur L.

246 desta G, deșta DL.

247 Bahli L.

248 Baguzeinda G.

249 Bhayadanta D, Bayanta K, Bagyananta G.

250 Nagrada, Upasa K, Upasanda, Naghradanta $\mathrm{L}$.

251 Wiradagra om. G.
252 Nilabajra G.

253 Susindra K, sugindra L.

254 Kulabajra Ketabajra $\mathrm{G}$.

255 desta G, Theșta L.

256 Tunda, Tamaratrena $\mathrm{K}$.

257 manira $\mathrm{K}$.

$258 i k i$ L.

259 awakĕna K.

260 ta om. G.

261 datěn $\mathrm{K}$.

262 in L.

263 ambakta GK.

264 akwch $\mathrm{K}$. 
king Dharmarāja, king Wiṣnu, Namandara, Kalandaka, Pusandara, Ugrabāṇa, Managanda, Rukmasanda, Ruksmagana, Wiroṣa, Sanamanda, Sugradana, Waradāgra, Wișāna, Warada, Wisandara, Pratasura, Jātawara, Wijāta, and Sujāta, the king of Mandiratiga; the king of Antasara, called Candrapana; his seventeen sons, called king Sudarga, Dunagra, Wigrana, Grana, Supada, Daragra, Namasanda, Pradasa, Mānadhana, Mornaba, Isaka, Susenda, Wṛsesa, Wṛsenda, Jayanda, Wijakesra, king of Prasuba, and Dewara; a group of nine kings, called king Banaba, Banajaya, Sayastra, Durbhanga, Graganda, Wigrada, Sulaja, Wirasanka and Wradara, king of Burikatana; the king of Palawa, called Aruna, forming a group of seven with his brothers; the names of his younger brothers are king Sutāgra, Dasapata, Wirrakātma, Prasuta, Bisaka and Jayabāhu; the sons of king Bajrada, king of Wilatma, twenty-one brothers: the eldest Banli and the others Sinhātma, Sinhawadana, Bahuwinda, Bāhyadanta, Nagradanta, Upasanda, Wiradagra, Manamoha, Katagna, Sanawira, Nilabraja, Sugindra, Wasnajana, Suprajana, Wisanda, Kulabra and Ketabraja; the king of Gopalla and his brothers, eleven together: the eldest is called king Himacandra, then Ganindra, Gameka, the king of Tundaga, king Trana, Padmaketu, Maya, Sulandrasta, Sujaraja and Měta; the king of Mayūra, king Śubhadatta; the lord of Mālawa, king Indupati and the 85b lord of Widarbha, king Bhoja. That is a full hundred." Kālaweśma said: "Well, king Purușāda, I have no wish for all these kings; 33 the man I wish for is the king of Hastina, named king Sutasoma; if you can capture him, you may let loose these one hundred kings!"

So king Naramānsa departed and marched upon Hastina. Then, suddenly, there came the reverend Winayana, ${ }^{34}$ who feared for king Puruṣāda and advised him to take many troops with him: "Many kings 
nātha mari riku,265 sěsěk kuṭa iku de nin prawira." Mañka 266 inutus maraja Koṣa, Srawañga, Kalingarāja ; mañkwa binakta ratu tětělu 267 ika saha bala. 268 Tan makạ̣at prāpten hen nin pura Hastina; geger harohara sakuța Gajāhwaya. Mijil sañ Sutasoma lawan patnī nira, tan pasuñ aprana; tuwin 269 sañ Daśabāhu, śāla, Sucitra, Dakṣa, śālārdhana, ${ }^{269^{\mathrm{a}}}$ len para prabhu samadaya, mwan san apatih Jayendra, sami ahyun amĕdalana laga, tan sinun de san Sutasoma; lin ira sań nareśwara : "Sin amapaga 270 sira pějah." Matur sañ Jayendra: "Pukulun, aniwasi 271 rin asewaka Pāduka 272 Bhațāra. Punapi si depunayunayun 273 si kawulāsawita, yen tan matya! Punapi hurupanipun 274 si dāna 275 sāma nin Pāduka Bhațāra!" Tan apañjan hatur ira 276 patih; śīghrāmwit manĕmbah, tumuluy 277 mankat saha bala; tumut para prabhu. Tumuli 278 sań Śālārdhana. mañkat saha bhṛtyakrama sira mungw in ratha, dinulur in para kṣatriya, kadi puṣpa manẹdẹn; hanāhawan 279 kuñjara, śakaṭa hastī 280 aśwa, mwañ sañ śāla, Dakṣa, Sucitra; len maraja Daśabāhu mungah 281 in ratha; sĕk tan̉ balakrama. Añlin maraja Jinakula; "Sakehe won̉ apran iki kabeh mati měne." Mañkwa sumahur para pañcaka ika: "Kaki prabhu, sampun karěnö panandika nira iku."

Tan warṇana $281^{\mathrm{a}}$ san் karīn pura, warṇanĕn sañ apraǹ mapagut, manilonilinonan. 282 Sampyuh 283 tekañ laga. Sañ Duloma pějah de san Śāla. Sañ Dumendagra pějah de san Śālārdhana. San Pakṣīndra pějah de sañ Śālārdhana. Sañ Subhanga pějah de sań Citrañsa. San் 86a Sumala pějah de sañ / Śāla.284 Sañ Sutîkṣna pějah de sañ Jayendra. Sañ Citrañsa pějah de sañ Dumdumbika. Sañ Dumdumbika pějah de sañ Jayendra. Sañ Mohānala, Mukhāgni, Caturkāya, Dhūmawadwa pějah de san Sinhaghoșa. Maraja Sinhhaghoṣa pějah de sañ Kalingarāja. Sañ Kalinga pějah de sañ Māruta. Maraja Māruta pějah de sañ Koṣa. Sañ Cedi pějah de sañ Siwanda; lan nara sinatriya 285 akweh pějah. Maraja Koṣa, Siwanda pějah de sañ Daśabāhu. Sañ Daśabāhu, sañ śāla pějah de sañ Puruṣãda. Sañ Dakṣa pějah de sañ Wimona. Sañ

\begin{tabular}{|c|c|c|c|}
\hline 265 & marcriku $\mathrm{K}$. & 273 & dcpunahyınahy'un D, \\
\hline 260 & Mainkzoa $\mathrm{K}$. & & de pun ahyıunhyun $\mathrm{K}$. \\
\hline 267 & tatělı $\mathrm{K}$. & 274 & si depunayunajun ... \\
\hline 68 & saha bala $\mathrm{GK}$, & & urupanipun om. G. \\
\hline 269 & $\begin{array}{l}\text { Soegiarto; sabala L. } \\
\text { torvin } \mathrm{K} \text {. }\end{array}$ & 270 & $\begin{array}{l}\text { urupanipun pidana ?? } \\
\text { Soegiarto. }\end{array}$ \\
\hline $39 \mathrm{a}$ & Ardhana KG. & 276 & $I \mathrm{~K}$ \\
\hline & apapaga $\mathrm{K}$. & 277 & tumuli L. \\
\hline & aněda $\operatorname{sih} \mathrm{G}$. & 278 & Tumulıy K. \\
\hline & asewaka ri pāduka $\mathrm{G}$. & 279 & ana aze'ahana $\mathrm{K}$. \\
\hline
\end{tabular}

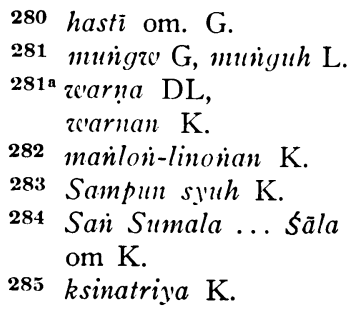


stay at that court; the city is crowded with heroes." So Puruṣāda summoned king Koṣa, Srawanga, and the king of Kalinga and took these three kings and their troops with him. Without delay he came before the city of Hastina; all the city of Gajāhwaya was in stir and commotion. Sutasoma, together with his consort, came out of the palace, and forbade to make war. Daśabāhu, śāla, Sucitra, Dakṣa, śālārdhana, ${ }^{35}$ all the lords and the prime minister Jayendra, all wanted to sally forth to battle, but Sutasoma did not allow them; the king said: "The man who takes the field will die." Jayendra spoke: "My lord, Your Majesty wrongs His followers. What would it mean to be beloved by devoted servants, if they would not die [for their master]! What would be the return for Your Majesty's liberality and kindness!" The prime minister made no long speech, soon he took leave with a bow and immediately marched out with his troops; all the kings followed him. Immediately after them śālārdhana left, standing in his chariot, with all his men in orderly array; the knights - as it were fresh flowers - and śāla, Dakșa and Sucitra accompanied him; some rode on elephants, some drove waggons drawn by elephants or horses. And king Daśabāhu drove a chariot. The ranks of the troops followed close upon each other. The king, Jina's son, said: "All these men that go out to war will die ere long." But the religious men replied: "Dear king, let us not hear these words of yours."

Let us not tell of those who stayed behind in the city, let us tell of those who came to meet each other in combat, inflicting losses upon each other. Men fell on both sides in this battle. Duloma was killed by śāla. Dumendagra was killed by śālārdhana. Pakṣindra was killed by Śālārdhana. Subhanga was killed by Citranisa. Sumala was killed by

86a Śāla. Sutîkșna was killed by Jayendra. Citransa was killed by Dumdumbika. Dumdumbika was killed by Jayendra. Mohānala, Mukhāgni, Caturkāya and Dhūmawadwa were killed by Siǹhaghoṣa. King Sinhaghoșa was killed by the king of Kalinga. Kalinga was killed by Māruta. King Māruta was killed by Koṣa. Cedi was killed by Siwanda; and many knights were killed. King Koșa and Siwanda were killed by Daśabāhu. Daśabāhu and śāla were killed by Puruṣāda. Dakṣa was 
Jayendra pějah de sañ Naramāñsa. Sañ Sucitra malayu, mawarahi sañ Sutasoma yen yayah ira pějah de san hyañ Rudra.

śīghra masĕh maraja Sutasoma, inirin in bala, tan ahyun; paḍa kinon rumakṣa in purī, anhin raden Sucitra pinakahastaka lawan para pañcaka 286 mwañ butrawa pạ̣anitihi 287 dwirada. Prāpteñ samara, giněsěn de sañ Naramāñsa; tan gěsěñ, dadi amṛta; pạ̣a mahurip sakweh in huwus pějah. Krodha sañ Rudra, mahyun anikěp, tan kěna sinikěp, kady anikĕp wawayañan. Meran̉ sañ hyan Śiwa; ya ta manambut tomara; salwir in pṛsañka 288 dinukakěn, parěn sakoṭi luměpas, tan tumama rin san் Jinamūrti, těka, hilañ, dadi kusuma manĕdẹñ : cakra dadi padma, kanigara; bajra, gadāstra 289 dadi rankañ mas, kadya 290 jinĕm. Asuyi sañ hyañ Rudra, manambut giri sañjata,291 ginutukakĕn, dadi parigi, rĕmuk saken tanaan; daṅșțra hyan Parameśwara, tĕka, pupug ri san் Jinakula. Asuyi san் hyan் Rudra,292 ahyun manawakĕna bhuwana. Sawega paḍa tumurun para dewasangya: Indra, Yama,293 Baruṇa, Dhanendra, Gaṇa, Kumāra, paḍāmuhuti 294 sañ hyañ Bomakesa, mapan dudu sira sañ 295 apürba 296 jagat. Mañkwa mantuk in tungal ira rin san hyań Jina. Kari driya nira sañ Puruṣāda, tiba kadi gunun rubuh; tan makaḍat awunu, anĕmbahněmbah rin maraja Jina86b kula, / tan pahyun anaturěna 297 rin sañ Kālaweśma: "Mañka sira dadi apurohita nin 298 hulun." Lin san Sutasoma: "Sampun mańkana sań prabhu. Manawi kacacad sasaman ira ratu, karsa niñsun 299 aturěna kami." Mañka maraja Puruṣāda masunuta, kan tinanisan maraja Sutasoma; lin maraja Sutasoma: "Maraja Puruṣāda, yen sira harěp aguru rin hulun, aturěna kami rin bhațāra Kālaweśma." Mañkwa hinaturakěn hawan ratha akalihan lawan san் Naramānsa; tumut para nātha manirin. Bawis prāpten weśma Kāla; kapangih sañ Kālaweśma; lin sañ Purușāda: "Punika 300 ta, ${ }^{301}$ pukulun, kan dera palaku." Sukha bhatāa Kāla; sumahur sañ Jinakula: "E bhațāra Kālaweśma, yen insun dera

\footnotetext{
286 mañcaka G.

287 paḍa om. DK.

288 sakweh in prsanka

$\mathrm{D}$, sakwehin prasaika $\mathrm{K}$.

289 sanstra $\mathrm{G}$, danastra $\mathrm{K}$, danistra DL. Cf. Sut.k. CXXXVIII \&d sq. Gěk ghyěr těmpuh ikaì gadāstra tumiben kșiti dadi gěrěh in labuh kapāt// Ran்kan் mas těnah in
}

\begin{tabular}{|c|c|c|c|}
\hline & жrvay adbhuta murub & 293 & Yama \\
\hline & kadi siluman anindi- & 294 & pada mugut $i \mathrm{G}$, \\
\hline 290 & $\begin{array}{l}\text { tāhalēp/ } \\
\text { kadi D kadin } \mathrm{K}\end{array}$ & & pada amuhuti $\mathrm{K}$, \\
\hline 291 & girisada G, girisana & 295 & $\begin{array}{l}\text { san om. G. } \\
\text { sad }\end{array}$ \\
\hline & DL. Cf. Sut.k. & 296 & pūrna $\mathrm{G}$, apurbwa $\mathrm{K}$. \\
\hline & CXXXVIII9c : mwain & 297 & anaturana $\mathrm{K}$. \\
\hline & $\begin{array}{l}\text { tekañ giri sañjateka } \\
\text { rumawuh dadi parigi }\end{array}$ & 298 & $\begin{array}{l}\text { apurohitěnin̈ } \mathrm{G}, \\
\text { purohitanin } \mathrm{K} .\end{array}$ \\
\hline 292 & $\begin{array}{l}\text { rěmuk saken tanian/ } \\
\text { manambut giri ..... }\end{array}$ & $\begin{array}{l}299 \\
300\end{array}$ & $\begin{array}{l}\text { karsaninulun } \mathrm{K} . \\
\text { Puniki K. }\end{array}$ \\
\hline & $\begin{array}{l}\text { Asuyi san hyain } \\
\text { Rudra, om. } \mathrm{K} .\end{array}$ & 301 & ta om. L. \\
\hline
\end{tabular}


killed by Wimona. Jayendra was killed by Naramāñsa. Sucitra fled and reported to Sutasoma that his father had been killed by god Rudra.

Quickly king Sutasoma went to the battle-field; his soldiers wanted to escort him, but he did not allow them, he ordered them all to guard the city, only prince Sucitra he took with him as his charioteer and the religious men and brahmans followed him, riding elephants. When he came to the battle-field Naramānsa tried to burn him, but without result; the flames turned into nectar and all those who had been killed came to life again. Rudra got angry; he wanted to seize Sutasoma, but did not succeed, as if he tried to seize a shadow. God siwa felt ashamed, so he seized a lance, he let off all kinds of arrows : ten millions at a time flew through the air, but they failed to hit the Jina incarnate, lo, they vanished and became flowers in full bloom: discuses turned into lotuses and water-lilies; thunderbolts, clubs and arrows turned into a golden pavilion, as it were a bed-chamber. God Rudra was angry, he lifted up mountains for missiles and tried to hurl them at Sutasoma, but they turned into an embankment as they crashed down from his hand, and, lo, the fangs of god Parameśwara were blunted on Jina's son. God Rudra was angry, he wanted to annihilate the world. Hurriedly all the hosts of gods descended: Indra, Yama, Baruna, Dhanendra, Gaña and Kumāra, all stopped god Bomakesa, for he was not the god who had created the world. So he returned to unity with the lord Jina. The senses ${ }^{36}$ of Purușāda remained, ${ }^{24}$ he fell to earth like a crashing mountain. Soon after he regained consciousness and again and again

86b bowed to the king, Jina's son; he did not wish anymore to offer him to Kālaweśma: "Now be my chaplain." Sutasoma said: "Do not do so, king. If my equals, the kings, are injured, it is my wish that I shall be sacrificed." Now king Purușãda wept, he wept over king Sutasoma, but king Sutasoma said: "King Purușāda, if you want to be my pupil, sacrifice me to god Kālaweśma." So he went to be sacrificed, travelling by chariot together with Naramānisa; all the kings accompanied him. Presently they came to Kāla's abode and found Kālaweśma there; Purusāanda said: "This, my lord, is the king you asked for." God Kāla was happy. Jina's son said: "Well, god Kālaweśma, if you eat me, 
taḍah, uwakĕna ratu satus." Tuṣța san Kālaweśma, ya ta inuwakakĕn 302 de sañ Puruṣāda. Sampun ucul nātha śata, pạ̣a matur in maraja Sutasoma: "Aǹhur, pukulun, patik Bhațāra paděma sumadi 303 Pāduka Aji. Sampun Pāduka Bhatāra." Liǹ sañ Jinakula: "E san் prabhu uttama, awĕlas insun anak rabi nira, pạ̣a añunsi kuṭa niṅsun amĕlasakĕn. Lawan ta, sañ para nātha kabeh, rununĕn pitutur mami.304 Aja sira an̉larani hati nin won ; ajāmidaṇ̣̣a 305 tan sabĕnĕre; ajāmalat duwe nin wadwa nira; aja tan asih in daridra; luluta rin pandita; aja sira katuṅkul 306 in kagunan, amujya nabhaktya; 307 aja mamateni 308 yen 309 tan sabĕnĕre; uttama si yen 310 sira akalisa rin pati, sapuraha rin் tiwas, anulaha sāma dāna, ajāpilih jana.” Měněn para nātha, anuhu dudunya rin nuni; mañke ta paḍānanĕnañĕn wuwus san் Jinakula, sami amintuhu. ${ }^{311}$ Mañkwa ta 312 san் Sutasoma amalampah tinadah de sañ Kālaweśma. Ya ta pạ̣a matur para santāna, san Daśabāhu, Sinhaghoṣa, Citrañsa, Susena, Māruta, Cedi, Śāla, Dakṣa, Sucitra, mwan் sañ Puruṣāda nanis i jön sañ Jinakula. Lin san Sutasoma: "E para rāja, aja n amalan் 313 sira kabeh, tin̉halana balaka polah in̉sun." Mĕnĕn san் para santāna. Mañkwa sāhasa bhațāra Kālaweśma; mañkwa sinikĕp sañ nātha; pinañunusakĕn khaḍga; ahyun sinuduk,314 wurun்; ahyun pinran்,315 wurun; linumahakĕn, kinurĕbakĕn,316 wurun்; dinuga ñeñeret 317 rudhiranya. Mañkwa matĕmahan bhujaga san hyan் Kāla; ya ta inulu maraja Sutasoma, sampun kolu, pāda malĕr in tutuk, tan těken் garbha. Mañkwa makulasahan sañ hyan Kāla, kadi gĕni karasa rin garbha.318 Mojar san Jinakula rin jĕro garbha: 319 "E bhațāra Kāla, kuleh iṅsun nora dera 320 ulu pisan? Paran sañka nira olěg amanani 321 kami? Mapan hulun 322 denta kilala." Mĕněn san் hyan் Kālaweśma samby anĕmbahnĕmbah 323 rin san் Jinakula, lin் ira: "E san̉ Jinarāja, mĕtwa sira, ahuripa, pituturana mami; kami mañke apurohita rin sira." Sumahur maraja Sutasoma: "Tĕmĕn ta sira?" Lin sañ Kāla: "Singih, pukulun." Mañkwa mijil saken garbha sañ Kāla; tuṣta manah iǹ para rāja. Manikwa ta sañ Kālaweśma maguru

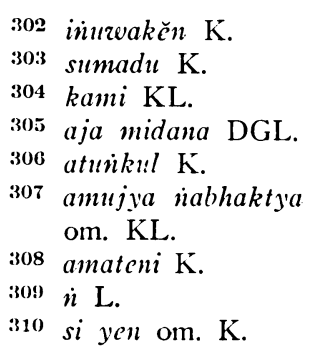

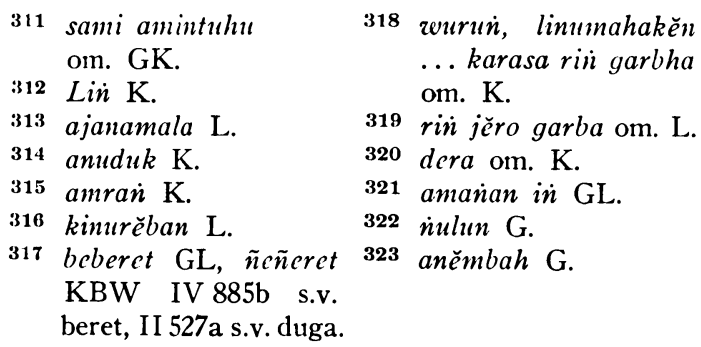

318 zurùi, linumnahakĕn ... karasa rin garbha om. K.

319 rin jěro garba om. L.

320 dera om. K.

321 amainan in GL.

322 iulun $\mathrm{G}$.

323 aněmbah $\mathrm{G}$. 
let the one hundred kings loose." Kālaweśma agreed and so Purusāda let them loose. Soon the one hundred kings were free and everyone of them offered himself to king Sutasoma: "My lord, Your Majesty's servant should rather die than Your Majesty. Your Majesty should not die." But Jina's son replied: "Well, excellent kings, I pity your children and wives, who have all resorted to my city, in a miserable state. And now, kings, listen all to my instruction. Do not injure the minds of the people; do not unjustly inflict punishments; do not appropriate your men's possessions; do not withhold your favour from the poor; be devoted to learned men; do not rely on your greatness, though people may honour you and pay you homage; do not put people to death, but for a just reason. Indeed, it will be best if you are indifferent to death and patient in adversity, if you are kind and liberal, without preference for anybody." The kings remained silent, they owned their former misbehaviour and now they all reflected upon the words of Jina's son and took them to heart. Now Jina's son asked Kālaweśma to eat him, but all his vassals, Daśabāhu, Sinnhaghoṣa, Citranisa, Susena, Māruta, Cedi, śāla, Dakṣa, Sucitra and Puruṣāda, offered themselves, weeping at the feet of Jina's son. Sutasoma said: "Well kings, do not oppose me, only see what I am going to do." The vassals fell silent. Now god Kãlaweśma rushed upon the king; he seized him and drew his sword; he tried to stab him, but to no effect; he tried to slash him, but to no effect; he laid him on the back, laid him face downwards, but to no effect; he tried to drink his blood. Then god Kāla assumed the form of a snake and swallowed king Sutasoma. He had soon been swallowed, but his feet remained in Kāla's mouth, they failed to come into his stomach. Now god Kāla writhed with pain, it was as if he felt fire in his stomach. Jina's son, in Kāla's stomach, said: "Well, god Kàla, why do not you swallow me completely? What is the reason that you have a dislike of eating me? For you asked even for me." God Kālaweśma paused and repeatedly paid reverence to Jina's son, saying: "O lord of the Jinas, come out, live, and give me instruction. I shall henceforth be your pupil." King Sutasoma asked: "Are you in earnest ?" And Kāla answered: "Yes, my lord." So he came out of Kāla, to the joy of the kings. And Kālaweśma became a pupil of Jina's son; soon 
rin sañ Jinakula; sampun winarah in kaśāntikan. ${ }^{324}$ Bhrașta sukha nin para nātha tuminhal in 325 san Sutasoma. Sampun winarah in aji, sampūrṇa nin rāga, ${ }^{326}$ paran in mati, sampūrṇa nin mati, tinĕmu nin mati, 327 hurip in mati, sampūrna nin apangih 328 lawan kañ ${ }^{329}$ pinangih. Sampun tĕlas pawarah sañ Jinakula; ya ta mantuk sań Sutasoma. Pinaraban san் Antakadwiman san Kālaweśma, kari matapen giri Gadarba.330 Mañkwa sawadwa nira maraja Puruṣāda paḍa mahurip de sań Jinarāja, mańkwa pạ̣a bhakti ri sañ Sutasoma, manut sa-ulah ira 331 saǹ Puruṣāda. Sampun pūrṇa 332 dānawa těken̉ turañga, wāhana, mwañ para nātha katiga. ${ }^{333}$ Ramya patut bala 334 danuja lan jana kabeh. Mañkwa mantuk in Gajāhwaya, inuparĕnga, hinarayana, paḍa tușța, mapatut saha krama.

87a Tucapa bhatāra Sura/nātha anrahakěn widadari, gañjaran ira analahakĕn asura, den kadi sañ Dhanañjaya. Mañkwa tinulak de sañ Jina. ${ }^{335}$ Lin san hyan Surapati: "Punapi ta,336 san prabhu, karan in tinulak?" Wikalpa nira sań Sutasoma matura yen sampun katẹ̣a sih in dewatā kabeh: "Gumanti ta manirānĕḍa huripane san nāthen Sin̉hala 337 sasantānabalaturañgane." Tuṣta sañ hyan śakra, lin ira: "Haywa sanśaya." Mańkwa inudanan amṛta, mańkwa paḍa mahurip saha bhṛtyakoṣa, wāhana; sakweh in abela paḍa mahurip. Mañkwa ta amicāra sañ nātha lawan para kṣatriya, mwan mantri naran Pramoda, mwañ ari, sañ Salwa, Kontara, Janaka, Kanggala, Ketu, Mãya, Śańkha, Racajana,338 Subala,339 Subalāntaka, ${ }^{340}$ paḍannaywani yen marěkeñ 341 Gajāhwaya. śighra mankat saha patnī mungw in ratha.

Tucapa wěruh san் Jinakula yen san் Jayawikrama marĕk saha patnī. Mankka kinen sirāyi nira amapaga saha pisalin tigan rañsukan 342 sowan garane kapitu, pạ̣a pisaliněn pin tiga sadina. Mañke prāpta sañ nāthen Sinhala, pinapag de san Puṣpawatī saha bhūṣana kapitu; paḍa pinisalin.Len maraja Jayawikrama, pinapag, ${ }^{343}$ pinisalin liman rańsukan, kaprabhun. Mwań para kṣatriya kasaña len san Pramoda pinisalin liman் rańsukan. Ramya patut lawan maraja Puruṣāda. Mañkwa ta kinen paḍa mantuka para prabhu ika, prasamāmwit sapurasapura, ${ }^{344}$

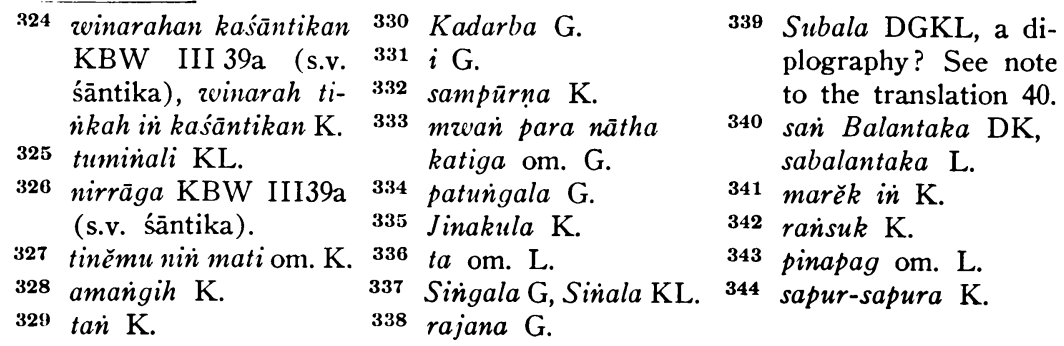

339 Subala DGKL, a diplography? See note to the translation 40. 340 sai Balantaka DK, sabalantaka L.

341 marěk in $\mathrm{K}$.

342 raisuk $\mathrm{K}$.

343 pinapag om. L.

344 sapur-sapura $\mathrm{K}$. 
he received instruction concerning tranquillity. The kings were completely happy when they saw Sutasoma. Soon [Kāla] was instructed in sacred knowledge: the perfection of the body, the way of the dead, the perfection of the dead, what the dead will find, the life of the dead, the perfection of those that find and the perfection of what they find. ${ }^{37}$ When he had finished his instruction, Sutasoma went home. Kālaweśma was given the name of Antakadwiman and remained behind on mount Gadarba, performing austerities. Now all the men of king Puruṣāda were brought to life again by the lord of Jinas and they all paid homage to Sutasoma and followed Purusaāda in every respect. Soon the dānawas were all restored to good health together with their horses and other riding-animals, and likewise the three kings. Danuja and human soldiers rejoiced and lived in good harmony. Now they returned to Gajāhwaya, were offered ornaments and were entertained; all were pleased and observed good customs in perfect agreement.

87a Let us tell how god Suranātha offered widadaris as a reward for defeating the asuras, in the same way as they were offered to Dhanañjaya. But the Jina rejected them. God Surapati asked: "King, why do you reject these?" Sutasoma respectfully answered that he thanked the gods for their favour: "Instead I ask that the king of Sinhala and his vassals, soldiers and horses may live." God śakra agreed and said: "Do not be troubled about that." So nectar rained down upon the fallen warriors and they all revived, together with their forces and mounts; and all the ladies who had followed their husbands into death 38 came to life again. Now the king deliberated with the knights, the minister Pramoda and his younger brothers, Salwa, Kontara, Janaka, Kanigala, Ketu, Māya, Śankkha, Racajana, Subala and Subalāntaka; they all thought it right to repair to Gajāhwaya. Quickly the king departed together with his wives, travelling by chariot.

Let us tell how Jina's son heard that Jayawikrama and his wives were coming to visit him. He let his wife go to meet them with three changes of clothes for each of the seven consorts, in order that they might change thrice a day. Now the king of Sinhala arrived and was received by Puspawati with the seven attires; all the ladies changed their dress. And king Jayawikrama, when he was received, was offered five suits of clothes, dresses befitting a king. And the nine knights 39 and Pramoda each were given five changes of clothes. They rejoiced 
saǹ nāthen Sinhala, Śrīmagadha, Srawañga, śrīkalininganātha, Dwārawatī, Wirāṭa, Welarāja, Cedi, Kuṇụ, Nalabeka, Lěnkendra, mwan nātha śata punika, paḍa mantuk saha gṛha, kabeh pạ̣a saha mṛdanga nungalnungal. An̉hin maraja Puruṣāda tan harěp mulihen̉ Ratnakaṇụa, wentěn in parwata manulahakĕn Jinasmṛti saha yodha, mantri nira kabeh, pạ̣ānulahakĕn kamaharddhikan; yodha, mantri pạ̣a mari buddhi $\mathbf{3 4 5}$ hinsaka.

87b Mañkwa san hyan் Jina mantuk in Jināla/ya. Sań śālārdhana pinakramakěn 346 putrī nira maraja Sin̉haghoșa, naran dewi Rukmawatī. Raden Śāla manalap putrī nira maraja Citraṅsa, naran san Antawatí, manaděg ratu rin Kāśīpati. Sañ Daśabāhu mantuk in Dakṣinālaya. Sań Sucitra manalap anak ira maraja Susena, naran dewī Rĕngawati, manadĕg 347 nāthen Kumbina. Sañ Dakṣa makrama ātmaja nira maraja Māruta, naran Sañkawati, manadĕg ratu rin Welarājya. Maraja Purușāda .... ${ }^{348}$ 
and became on good terms with king Puruṣāda. Then all these kings were dismissed and each of them took leave, the king of Sinhala, Śrimagadha, Srawanga, the king of śrīkalinga, Dwārawatī, Wirāța, the king of Wela, Cedi, Kundi, Nalabeka, the lord of Lènka and those one hundred kings; all went home with their wives, each preceded by drums. But king Purusaāda did not wish to return to Ratnakaṇ̣a, he stayed in the mountains concentrating his mind on the Jina. With him were all his soldiers and ministers, leading a holy life; the soldiers and ministers abandoned any thought of doing harm.

87b Now the lord Jina returned to Jina's abode. Sāāārdhana married king Sinhaghoṣa's daughter, called princess Rukmawatī. Prince śāla took to wife king Citransa's daughter, called Antawatī, and came to the throne as king of Kāśī. Daśabāhu returned to Dakṣinālaya.40 Sucitra took to wife king Susena's daughter, called princess Rĕngawati, and came to the throne as king of Kumbina. Dakșa married king Māruta's daughter, called Sañkawati, and came to the throne as king of Wela, King Puruṣāda... ${ }^{41}$ 



\section{NOTES TO THE TRANSLATION}

1 Nearly the same genealogy is given CP 70a. There

(1) Kālakeya is the son of Kudagra (Kubagra $\mathrm{K}$ );

(2) Hiranya's wife is called Mursina (Mursini K);

(3) their sons are Selara, Sakuni (dudu Sakuni Korawa, Sakuni danuja, i.e. "not śakuni the Korawa, but Sakuni the danuja"), Kruddhākșa, Dușkrta and Mānakañśa. Cf. Arjunawiwāha XXI. 2bc: krüdhākșa dușkṛta wirakta karālawaktra, wetbet hiranya-kasipuh kula kālakeya, i.e. "K., D., W., and K., offspring of Hiranya (and?) Kaśipu, from the race of Kālakeya." According to CP 70a Wirakta and Karālawaktra are among the 100 sons of Kaśipu. Cf. also Smaradahana XXX. 5ab (considered spurious by Poerbatjaraka): $i$ zeuri tumüt hiranya-kasipuh mwan asura winuruk/ wěka-wěka kālakeya.... i.e. "In the rear followed Hiranya (and?) Kaśipu and shrewd asuras, sons of Kālakeya...."

2 In Sut.k. (XXI. 3 sqq.) these monstrosities are only ascribed to Sūciloma, who was reborn as Purușāda.

3 This feature is not found in any of the recensions of the story of Kalmāṣapanda brought together by Watanabe (see p. 10, note 34), but Dr. Pigeaud kindly draws my attention to two parallels. In the Lakon Bațara Kala, Dewi Uma gives her children janian (Modern Javanese for gaian) ares to eat. As she prepares the food she cuts her finger and the blood falls upon the portion for Bațara Kala (the fourth son of Bațara Guru and Dewi Uma). He asks his mother for more, but she tells him to ask his father. Bațara Guru gives him the recipe: several children are wanted as ingredients. So Batara Kala becomes a lonely man-hunter, but people finally get help from Dalan Putus (the same person as Sĕmar), who succeeds in stopping and satisfying Bațara Kala. This wayan play has a ritual function, viz. the purification (ruwat) of a person. See Th. Pigeaud. Aanteekeningen betreffende den Javaanschen Oosthoek, TBG LXXII (1932), p. 284 sq. In the tale of Lara Jongran of Prambanan (related by J. W. Winter, Beknopte Beschrijving van het hof Soerakarta in 1824, BKI LIV (1902), p. 92) the cook of raja Gupala cuts his finger, the blood is mixed with the food he is preparing, with the same result for Raja Gupala as for Purușāda. In Sut.k. (XXII. 6) the food intended for the king is stolen by dogs and swine, and the cook, failing to find other food, cuts a piece of flesh from the thigh of a dead human body; a close resemblance only with the Pāli Mahāsutasoma-jātaka.

4 CP 47ab gives a list of the Korawas, which only partly agrees with those in MBh. (I. 108) and Ādip.OJ (114). Wirabāhu is found in all the three lists, Sranama in none of them. The CP list only has sain Sanama.

5 By Pāṇạa Yudhișthira is meant. Sut.k. (XVIII. 2 - XIX. 3) gives a different account of the descent of Sutasoma's mother (who is called Prajñādhari there) : Rawibhoja has two sons, Subala and Jayatsena. Jayatsena becomes a hermit under the name of Sumitra. Candrasinha and Prajñādharī are the children of Subala. Prajñädhari’s husband is called Mahāketu (I. 5) and is said to belong to the dynasty of the Kurus (in accordance with an Indian tradition: Āryaśūra's Jātakamālā and Mahā-Sutasoma-jātaka) and to reign in Hastina. The parwa 
author probably deliberately breaks with this tradition, because as a descendant of the Kurus Sutasoma would be on the losing "left hand" side. By making the hero a descendant of Pandawa he brings him to the victorious "right hand" side. This distinction between "right hand" side and "left hand" side, as is well known, is essential in wayan. Cf. Introduction $\S 17$.

6 This passage implies that the prince is an avatar of Brahmā. He is often called Dhätrātmaja or Dhätrputra and at his death returns to Brahmā's heaven, Dakșinālaya (87b).

7 She is called Candrazvati in Sut.k.

8 Member of a certain social group, a country gentleman?

8a $<$ Bajra-kāla? Cf. Hooykaas AT p. 223 ad $\S 42$.

$9<$ Sry Awanga. See p. 9, note 27.

10 In Sut.k. (LVII. 13-16) Koṣa of Magadha is the younger brother of Dewāntaka of Āwanga. Koṣa sues for Puṣpawati, the daughter of the king of Mālawa, but she is married to Daśabāhu. Now, Dewāntaka (evidently on behalf of his brother) asks for the hand of Daśabāhu's sister Candrawatī, but is rejected. Hence a war, ending in the defeat of Dewāntaka and Koṣa and their seeking refuge with Purușāda.

10a Cf. 23a: dalidra/ pandita// daridra/ wwan kasyasih//

11 KBW IV. 803b s.v. gambain: ginamban, "beheaded?"

12 The capital of Purușāda.

13 According to Tantular Daśabāhu's wives are Puṣpawatī, Wișatī, the daughter of a muni, and Sulakșmini, the daughter of a brahman. Their respective sons are Sāla, Sucitra and Dakṣa.

14 From Sadabhijna a, Buddha.

15 The translation of many of these words for diseases and defects is tentative only. CP gives a list of such evils (praceka nin mala) 46a sq. A similar case of miraculous healing, at the birth of Suprasena, is narrated CP 220 . Cf. also J. Brandes, TBG XXXII (1889), p. 593.

16 I.e. the Javano-Balinese year of 210 days. těmu bañu seems to be an idiomatic expression conveying the notion of a movement or action which, by coming back to the starting-point, is complete. A Balinese synonym is němu gělan (gĕlan = bracelet), which means "to come back to the same point", said e.g. of 1) a star in the sky, 2) a day in the Javano-Balinese calendar, 3) the beginning of the krtayuga after the lapse of four yugas.

17 Dimpa is perhaps the Averrhoa Bilimbi L. or the A. Carambola L., uwi the Dioscorea alata L.

18 And other recluses.

19 Obviously Sumitra is meant, but then the author of CP here follows Tantular's account of the genealogy and not his own one. Cf. $78 \mathrm{~b}$ and p. 59 , note 5 .

${ }^{19 a}$ On this ritual see C. Hooykaas, Sūrya-sevana, the way to God of a Balinese Siva-priest. Verhandelingen KNAWL, NR dl. LXXII No. 3, Amsterdam 1966. Cf. p. 61 , note 28 .

20 Against Gajawaktra.

21 The resort of Gajawaktra. The wild kapok tree (kĕpuh) is the Bombax malabarium D.C.

22 This "Elephantsface" is alternately called Nekapaw'aktra, Wāranawaktra, Dipakwadana, Samberawaktra, Wãranakuñca, Sāmajawaktra and Dwiradamukha.

23 This arrow has emanated from Sutasoma's concentration and has miraculous power.

24 The god Gana (Ganeśa) hitherto has dwelt in Gajawaktra, thus giving him extraordinary power. Now Sutasoma's arrow makes the god withdraw from 
Gajawaktra's person, who is left a common creature. The same relation obtains between Rudra and Purușāda; cf. 86a. Purușāda is therefore sometimes called Rudra and even Sizera, Parameśzuara or Bomakesa (from Byomakeśa, Skt. $V$ yomakesa). It will be observed that this is something different from the relation between a god and his avatar (Jina - Sutasoma; Dhātṛ - Daśabāhu).

$25 \mathrm{He}$ is also called Nãgapāśa.

25a This passage is the Vyāghri-jātaka, well known from Sanskrit Buddhist literature. Cf. L. Feer. Le Bodhisattva et la famille de Tigres. JA 9. XIV. 272 sqq.

26 According to Sut.k. LII. 12 as Wairocana.

27 Siwa, Iśwara, Maheśwara, Brahmā, Rudra, Mahādewa, Sañkara, Wiṣnu and Sambhu. Cf. P. H. Pott. Yoga and Yantra.... (The Hague, 1966), pp. 132 sqq. Rudra is mentioned once more separately, probably on account of his important role in this tale.

28 Of the Doctrine? But holy water (often called amrta) is of paramount importance in Balinese religion as a means of ritual purification. It is made in sūryasevana, the ritual just celebrated by Sutasoma. Cf. p. 60 , note 19a.

29 In Sut.k. (LVII. 20a and LXVI. 1a) this park is called Ratnalaya ("abode of jewels"), a name well justified by its description.

$30 \mathrm{Sc}$. in a pond in the park. In Sut.k. (LXXIII) there are four crocodiles.

30a The wounded foot, apart from Sut.k., has a parallel only in the Mahāsutasomajātaka.

31 In Sut.k. (CX. 14a and CXL. 9d) (hyañ) Kālaweśma is the name of a mountain, "the abode of Käla."

32 In Sut.k. (XCIV. 3) he promises to sacrifice a hundred kings in the wood (macarva ratu satus in wana).

32a In Balinese religion Käla-bhakșa "food for Kāla" is a standing term for children whose birth is in some respect inauspicious (e.g. twins of different sex, children born in the week Wayan). They are supposed to be doomed to serve as food for the god, unless an exorcism (panilukatan), including a wayan performance, is performed by a dalan. Cf. Mc Phee. Wajang koelit, p. 29b sqq. and my summary in HNF XXIX 196.

33 Because they have little merit and force, are defiled, no good food and tasteless (hinagunālpaśakti kalușa ndātan subhukty àsěpa/ Sut.k. CXI. 1b).

34 Nārada.

35 I.e. Ardhana. Sãla and Ardhana are frequently mentioned in the same breath in Sut.k.

36 The ten senses of Indian physiology: the animal organism.

37 A similar enumeration of topics CP $77 \mathrm{~b}$.

38 This event is related at length Sut.k. CII-CVII.

39 Obviously Jayawikrama's younger brothers, but above (87a) ten names are given, in accordance with Sut.k. XCVII 11; cf. p. 17, § 17.

40 Brahmä's heaven. Cf. p. 60 , note 6.

41 To judge from Sut.k. not much of our tale has dropped out here. We supply the rest of the sentence broken off in CP from Sut.k. CXLVII 21b sain sir bhüpati Ratnakanda matěmah Jinaparizuara rin Jinālay'a, i.e. "H.M. the king of Ratnakaṇụa [Purușāda] became an attendant to the Jina in Jina's abode." After that Tantular concludes with Ardhana's succession to the throne, which $\mathrm{CP}$ has already told. 



\section{INDEX OF NAMES}

\section{$\mathbf{A}$}

Anīlā 78a.

Antakadwiman 86b.

Antakāmṛtā 84a.

Antasara 85a.

Antawatī 87b.

Ardhana 84a.

Aruna 85a.

Asuraparaśujaya 83b.

Asurawijña 83b.

Atri 78b.

Awanga 83b.

B

Bahuwinda 85a.

Bāhyadanta 85a.

Bajra 78a, 84b.

Bajrada 85a.

Bajrānala 80a (2x).

Banaba 85a.

Banajaya 85a.

Banili 85a.

Baruna 86a.

Bhațāin 81a.

Bhimabala 78b.

Bhoja 84b, 85a.

Bisaka 85a.

Bomakesa 86a.

Braja 80a, b.

Brajakala 79a.

Burikatana 85a.

\section{$\mathbf{C}$}

Candranātha 78b.

Candrapana 85a.

Candrasinha 78b, 79a, b, 80b.

Cārudeșna 80a.

Caturkāya 86a.

Caturmukha 79a.
Cedi 86a, b, 87a.

Citrañsa 85b, 86a, b, 87b.

Cora 78a.

\section{D}

Dakșa 81a, 83b, 85b, 86a, b, 87b.

Dakṣinālaya $87 \mathrm{~b}$.

Daragra 85a.

Daśabāhu passim.

Dasapata 85a.

Dewara 85a.

Dhanañjaya 87a.

Dhanendra 86a.

Dharmarāja 85a.

Dhātṛ 79a (3x).

Dhātrātmaja 79b, 80a $(2 \mathrm{x}), \mathrm{b}$, $83 b(3 x), 84 a$.

Dhātṛputra $80 \mathrm{a}, \mathrm{b}(2 \mathrm{x})$.

Dhümawadwa 78a, 86a.

Dipakwadana 81b.

Duloma 78a, 85b.

Dumala 84b.

Dumdumbika 84b, 86a (2x).

Dumendagra 84b, 85b.

Dunagra $85 a$.

Durbhanga 85a.

Durlakșana 78a, 84b.

Durmendagra 78a.

Duṣkrta 78a.

Dwārawatī 87a.

Dwiradamukha 81b, 84b.

$\mathbf{G}$

Gadarba 86b.

Gajāhwaya 84a, 85b, 86b, 87a.

Gajawaktra 81b, 82b.

Gameka 85a.

Gaña 81b, 86a.

Ganindra 85a.

Girirāja 81b. 
Golakșa 84b.

Gopāla 85a.

Gori 81b.

Graganda 85a.

Grana 85a.

\section{$\mathbf{H}$}

Hastina 78b, 81a, 84a, 85b.

Hastināpura 84a.

Himacandra 85a.

Hiranya 78a.

\section{I}

Indra 82b, 83a, 86a.

Indrabajra 78a, 84b.

Indupati $85 \mathrm{a}$.

Isaka $85 a$.

\section{J}

Janaka 87 a.

Janati 85a.

Jātawara 85a.

Jayabāhu 85a.

Jayanda 85a.

Jayasurāga 79a, 84a.

Jayawikrama 87a.

Jayawirota 79a, b, 80a, b.

Jayawișnu 78a, 83a, b.

Jayendra 85b, 86a (2x).

Jina 87a.

Jinakula 82a, b, 83a, b, 84a, 85b,

Jinālaya 87 a.

$$
86 \mathrm{a}, \mathrm{b}(8 \mathrm{x}), 87 \mathrm{a} \text {. }
$$

Jinamūrti $81 b, 84 a$.

Jinarāja $86 b(2 x)$.

\section{$\mathbf{K}$}

Kāla 86b.

Kàlakeya 78a.

Kalandaka 85a.

Kālaweśma 84b, 85b, 86b.

Kalinga 79b, 86a.

Kalingapati $80 \mathrm{a}(2 \mathrm{x})$.

Kalingarāja 80b, 83b, 85b, 86a.

Kalușa 78a, 84b.
Kañgala 87a.

Kāśīndra 83a.

Kāśīpati 79b (3x), 80a, b (2x), 81a, $83 \mathrm{~b}, 87 \mathrm{~b}$.

Kaśipu 78a.

Kāśipura 79b, 84a.

Kāśīiājaputra 80a.

Katagna 85a.

Kendriya 82b.

Keśawa 78b, 81b, 82b, 83a, b.

Ketabraja 85a.

1. Ketu 78a, 84b.

2. Ketu 78b.

3. Ketu 87a.

Khara 78a.

Kontara 87a.

Kopa 82b.

Korawa 78b, 79a.

Koșa 79a, b (4x), 80a (4x), b $(2 \mathrm{x}), 85 \mathrm{~b}, 86 \mathrm{a}(2 \mathrm{x})$.

Kruddhākșa 78a.

Kubhūmi 78a.

Kulabra 85a.

Kumala 78a.

Kumāra 86a.

Kumbina 87b.

Kunḍi 87a.

Kuraṇ̦a 83b.

$\mathbf{L}$

Lěnika 85a, 87a.

\section{$\mathbf{M}$}

Magadha 79a.

Magadharāja 80a, 83b.

Mahāmeru 82b, 83a.

Mālawa 79b (4x), 80a (3x), $80 \mathrm{~b}(2 \mathrm{x}), 84 \mathrm{~b}, 85 \mathrm{a}$.

Mālawarāja 80a.

Mālawapati 80a, b.

Mālyawān 78a.

Mānadhana 85a.

Managanda 85a.

Mānakańśa 78a.

Manamoha 85a.

Mandara 81b.

Mandiratiga 85a.

Mãruta $86 \mathrm{a}(2 \mathrm{x}), \mathrm{b}, 87 \mathrm{~b}$.

1. Maya $78 b(2 x)$. 
2. Maya $85 \mathrm{a}, 87 \mathrm{a}$.

Mãya 87a.

Mayūra 85a.

Měta 85a.

Mohānala 86a.

Mornaba 85a.

Mukhāgni 86a.

Musina 80b.

\section{$\mathbf{N}$}

Nāgapāśa 82a.

Nagradanta 85a.

Nalabeka 85a, 87a.

Naladeka 80a, b.

Namandara 85a.

Namasanda 85a.

Naramāṅsa 84b, 85b, 86a, b.

Nekapawaktra 81b.

Nīlabāhu $80 \mathrm{a}, \mathrm{b}$.

Nilabraja 85a.

Nisati $80 a$, b.

\section{$\mathbf{P}$}

Padmaketu 85a.

Pakṣindra 85b.

Pakșīndrawaktra 84b.

Palawa 85a.

Pañcakadipak 82b.

Pañcawatī 81b.

Pāṇạawa 78b, 79a.

Pantarabhūmi 79a.

Parameśwara 86a.

Pāśarāja 81b.

Paśubrata 85a.

Paśupati 78a.

Pradasa 85a.

Praduharșa $80 \mathrm{a}, \mathrm{b}$.

Pragupta $80 \mathrm{a}, \mathrm{b}$.

Prajādharī 78b (2x), 81a.

Prajāpati 79a.

Pralěmba 78a.

Pramoda 87a.

Prasala 85a.

Prasuba 85a.

Prasuta 85a.

Pratasura 85a.

Prawasta $80 \mathrm{a}$, b.

Priyawatī 79b, 81a.

Pṛthiwi 81b.
Puhunbhikșuka 82b.

Purușāda, Purosada passim.

Pusandara 85a.

Puṣpawati 79a, 83b (2x), 84a, 87a.

\section{$\mathbf{R}$}

Racajana 87a.

Rājalakșmī 79a.

Ratmaka 78a.

Ratnakaṇda 80b, 87a.

Rĕnngawati $87 \mathrm{~b}$.

Rewatī 78b (2x), 79a (3x), 80b.

Rudra 82b, 84b, 86a (3x).

Rukmaketu 85a.

Rukmaratha 78b.

Rukmasanda 85a.

Rukmawatī 87a.

Ruksmagana 85a.

Sadabija 81a, 82b.

Sakra 82b (2x), 87a.

Sakuni 78a.

1. Sāla 81a, 83b, 85b, 86a (2x), b, 87b.

2. Sāla 85a.

Sālārdhana 85b (4x), 87b.

Salwa 87a.

Sāmajawaktra 81b, 82a.

Samberawaktra 81b.

Sanamanda 85a.

Sanawira 85a.

Sankawati 87b.

Sankha 87a.

Satradharma $78 \mathrm{~b}$.

Sayastra 85a.

Sindhurāja $79 b$.

Sinhaghoșa $86 a(2 x)$, b, 87b.

Sinhala $84 b, 87 a$.

Sinhātma $85 \mathrm{a}$.

Sinhawadana $80 \mathrm{a}, \mathrm{b}, 85 \mathrm{a}$.

Siwa 86a.

Siwanda 79a, 80a, b, 86a (2x).

Smarawanā 78b.

Solara 78a.

Somadatta 78b.

Sranama 78b.

Srawanga $79 \mathrm{a}, 80 \mathrm{~b}, 85 \mathrm{~b}, 87 \mathrm{a}$.

Srawangapati $83 \mathrm{~b}$.

Srawañgarāja $80 \mathrm{a}$.

Śrikalinga 87a. 
Śrimagadha 87a.

Subala 87 a.

Subalāntaka 87a.

Wagiswaragnyanasrawa 81a.

Subhadatta $85 a$.

Walabita 85a.

Subhanga 78a, 84b, 85b.

Subrata 85a.

Walasri 85a.

Wallabha 85a.

Sucitra 81a, 83b, 85b, 86a (2x), b, 87b. Wanawatī 78b, 82b.

Sudarga 85a.

Sudasasuta 82b.

Warada 85a.

Sudasātmaja 78 a.

Waradāgra 85a.

Sudasmini $80 \mathrm{~b}, 81 \mathrm{a}$.

Wāraṇakuñca 81 b.

Sugindra 85a.

Sugradana 85 a.

Wāranawaktra 81b, 82a.

Wasnajana 85a.

Sujaraja $85 a$.

Wela 87a, b.

Sujāta 85a.

Sūlabajra $80 a$, b.

Sulaja 85 a.

Sulamañru $80 \mathrm{a}, \mathrm{b}$.

Sulandrasta $85 a$.

Sumala 78a, 84b, 85b.

Sumina 78a.

Sumitra 78b, 81b, 82b, 83a.

Supada 85a.

Supadira 80 a, b.

Suprajana $85 a$.

Sürajana $85 a$.

Suranātha 86b.

Widarbha $84 \mathrm{~b}, 85 \mathrm{a}$.

Surapati 87 a.

Wigrada 85a.

Wigrana 85a.

Wigransu 85 a.

Wijakesra 85a.

Wijāta 85 a.

Wikampya 84b.

Wikarna $80 \mathrm{a}$, b.

Wikațākṣa 84b.

Wilatma 85a.

Wimona 78a, 84b, 86a.

Winayana $85 \mathrm{~b}$.

Wĩrabāhu 78b.

Wiradagra $85 a$.

Susena 86b, 87b.

Susenda 85a.

Suśrawa 79b, 80b.

Wìrakātma 85a.

Wirasanda $85 \mathrm{a}$.

Sutāgra 85a.

Sutasoma passim.

Sutikṣna 80a, b, 86a.

Swalandi 85a.

Wirasanka 85a.

Wirāta 87 a.

Wiratma 78a.

Wiroddhata $80 \mathrm{a}, \mathrm{b}$.

1. Wiroșa $80 \mathrm{a}, \mathrm{b}$.

2. Wiroșa 85a.

Wiṣāna 85a.

Wisanda 85a.

$\mathbf{T}$

Wisandara $85 a$.

Wisastri 80b, 81a.

Trana 85a.

Tundaga 85a.

Wiṣnu 85a.

Wisradana 85a.

Wisradika $80 \mathrm{~b}$.

Wradara $85 a$.

$\mathbf{U}$

Wrsenda 85a.

Wrisesa 85a.

Ugrabāṇa 85a.

Upasanda 85a.

Yama 86a.

Uragadwiman 82b. 


\section{KONINKLIJK INSTITUUT}

VOOR TAAL, LAND- EN VOLKENKUNDE

\section{VERHANDELINGEN}

1. H. Terpstra, De Factorij der Oostindische Compagnie te Patani. 1938.

2. E. J. van den Berg, De val van Sora. 1939.

3. C. Nooteboom, Oost-Soemba. 1940.

4. M. A.P. Roelofsz, De vestiging der Nederlanders ter kuste Malabar. 1943.

5. Hadji Hasan Moestapa, Over de gewoonten en gebruiken der Soendanezen. 1946.

6. J. J. Dormeier, Banggaisch Adatrecht. 1947.

7. W. F. Stutterheim, De kraton van Majapahit. 1948.

8. F. S. Eringa, Loetoeng Kasaroeng. Een mythologisch verhaal uit West-Java (Eerste gedeelte). 1949.

9. A. Teeuw, Hariwañśa. 1950. 2 delen.

10. G. Maan, Proeve van een Bulische Spraakkunst. 1951.

11. J. C. Anceaux, The Wolio Language. Outline of Grammatical Description and Texts. 1952.

12. J. Wils, Het passieve werkwoord in de Indonesische talen. 1952.

13. H. J. de Graaf, De regering van Panembahan Sénapati Ingalaga. 1954.

14. John Bastin, Raffles' ideas on the Land Rent System in Java and the work of the Mackenzie Land Tenure Commission. 1954.

15. Graham Irwin, Nineteenth-Century Borneo. A study in Diplomatic Rivalry. 1955.

16. C. Hooykaas, The Old-Javanese Rāmāyaṇa Kakawin with special reference to the problem of interpolation in kakawins. 1955. 
17. P. Donatus Dunselman O.F.M. Cap., Kana Sera. Zang der zwangerschap. 1955.

18. G. W. J. Drewes, Een 16de eeuwse Maleise vertaling van de Burda van Al-Būṣīīi (Arabisch lofdicht op Mohammad). 1955.

19. W. Kern, Commentaar op de Salasilah van Koetai. 1956.

20. G. J. Held, Waropense teksten. 1956.

21. H. R. van Heekeren, The Stone Age of Indonesia. 1957.

22. H. R. van Heekeren, The Bronze-Iron Age of Indonesia. 1958.

23. H. J. de Graaf, De regering van Sultan Agung en die van zijn voorganger. 1958.

24. G. W. J. Drewes and P. Voorhoeve, Adat Atjèh. 1958.

25. A. Teeuw, Lombok. Een dialect-geografische studie. 1958.

26. Teuku Iskandar, De Hikajat Atjèh. 1958.

27. H. J. Marks, The first contest for Singapore 1819-1824. 1959.

28. J. Brugman, De betekenis van het Mohammedaanse recht in het hedendaagse Egypte. 1960.

29. E. M. Uhlenbeck, met medew. van J. Soegiarto, Aantekeningen bij Tjan Tjoe Siem's vertaling van de lakon Kurupati rabi. 1960.

30. E. M. Uhlenbeck, Het systeem der Javaanse pronomina. 1960.

31. Jan van Lohuizen, The Dutch East India Company and Mysore 1762-1790. 1961.

32. Han Bing Siong, An Outline of the recent History of Indonesian Criminal Law. 1961.

33. H. J. de Graaf, De regering van Sunan Mangku-Rat I Tegal-Wangi, Vorst van Mataram, 1646-1677. I. De ontbinding van het rijk. 1961.

34. H. Myron Bromley, The Phonology of Lower Grand Valley Dani. 1961.

35. J. C. Anceaux, The linguistic situation in the Islands of Yapen, Kurudu, Nau and Miosnum, New Guinea. 1961. 